\title{
THE BARLEY CHLOROPLAST GENOME: PHYSICAL STRUCTURE AND TRANSCRIPTIONAL ACTIVITY IN VIVO
}

by

\author{
CARSTEN POULSEN
}

\author{
Department of Physiology, Carlsberg Laboratory, \\ Gamle Carlsberg Vej 10, DK-2500 Copenhagen Valby, Denmark
}

Keywords: Chloroplast DNA, restriction endonucleases, the large subunit of ribulose bisphosphate carboxylase, chloroplast RNA, formaldehyde agarose gels, Northern blotting, filter hybridization, light induced transcription.

DNA has been isolated from barley chloroplasts and analyzed with restriction endonucleases PstI, SalI, PvuII and HindIII. Fragments obtained by digestion with PstI and HindIII have been inserted in the bacterial transformation vectors pBR325 and pBR322 and amplified in Escherichia coli. The inserts of the recombinant plasmids have been mapped with the same restriction enzymes as the intact chloroplast DNA yielding a physical map for the barley chloroplast genome. It is a circular molecule about 133,000 basepairs in size, which is equivalent to the chloroplast genomes of other gramineae such as wheat and maize. Like these it has an inverted repeat, of about 20,900 basepairs, containing the genes for the ribosomal RNAs. There are many similarities of the barley, wheat and maize genomes with respect to recognition sites for the enzymes PstI, Sall and PvuII. Heterologous hybridization with a probe containing parts of the genes for the large subunit of ribulose bisphosphate carboxylase and for the dicistronic mRNA for two ATPsynthetase $\mathrm{CF}_{1}$ subunits, reveal that the position and organization of these genes in the barley chloroplast DNA are the same as found for maize and wheat.

Selected chloroplast DNA fragments isolated from the recombinant plasmids and covering about $80 \%$ of the genome have been used for hybridization to RNA purified from plastids of dark grown and 8 hours illuminated seedlings. The RNA was electrophoretically separated in denaturing agarose gels and subsequently Northern blotted onto DBM-paper. The DNA fragments were nick translated and hybridized to the filterbound RNA. A total of 70 transcripts ranging in size from 350 nucleotides to more than 6,000 were identified. Of these 11 were synthesized only after illumination of the seedlings. The transcripts encoding the large subunit of ribulose bisphosphate carboxylase and the ATP synthetase $\mathrm{CF}_{1}$ subunits $\beta$ and $\varepsilon$ have been tentatively identified. About 30 transcripts are larger than 3,000 nucleotides, indicating either the existence of a large number of polycistronic mRNAs or various forms of precursor RNAs.

Abbreviations: $b p=$ basepairs; DBM- = diazobenzyloxymethyl-; $\mathrm{DCCD}=$ dicyclohexylcarbodiimide; $\mathrm{DCMU}=$ dichlorophenyl-dimethyl-urea; $\mathbf{k b}=$ kilobases; $\mathbf{k b p}=$ kilobasepairs; $\mathrm{LS}=$ large subunit; NBM- = nitrobenzyloxymethyl-; NBPC = nitrobenzyloxy-methylpyridinium chloride; $\mathrm{pHvC}=$ recombinant plasmids carrying Hordeum vulgare chloroplast DNA fragments; $\mathrm{RuBPCase}=$ ribulose bisphosphate carboxylase. Genes: $r b c L=$ the gene for RuBPCase $L S$; atpA = the gene for ATP synthetase $C_{1}$ s subunit $\alpha$; atpB = the gene for ATP synthetase $C_{1}$ subunit $\beta$; atpE $=$ the gene for $\mathrm{ATP}$ synthetase $\mathrm{CF}_{1}$ subunit $\varepsilon$; atpH = the gene for $\mathrm{ATP}$ synthetase $\mathrm{CF}_{0}$ subunit III; psbA = gene for a 32,000 dalton photosystem II protein; $\mathrm{rrs}$, $\mathrm{rl}$ and $\mathrm{rrf}=16 \mathrm{~S}, 23 \mathrm{~S}$ and $5 \mathrm{~S}$ rRNA genes; trn = tRNA genes; pet = genes for photosynthetic electron transport proteins, cytochrome $f$. 


\section{INTRODUCTION}

The DNA found in the chloroplasts of green algae and higher plants has been isolated and studied for a number of species including Chlamydomonas reinhardti (30), Euglena gracilis (18), Spinacia oleracea (50), Zea mays (2), Triticum aestivum (9) and Pisum sativum (12). Fragment pattern analyses with restriction endonucleases have revealed that chloroplast DNAs (cpDNA) are circular, consist of 124,000 to 180,000 basepairs and frequently contain an inverted repeat of 20,000 to 25,000 basepairs. DNA-RNA hybridization studies showed the inverted repeat to house the genes for ribosomal RNAs (23S, 16S, 5S and others), the rrn-genes (6). One exception to this general organization is Euglena gracilis, which contains a triple tandem repeat of the rRNA cistrons and an extra copy of the 16S rRNA gene. The Leguminosae on the other hand contain only a single copy of the rRNA cistrons (35). Positions of the genes for some of the 30-40 chloroplast tRNAs (trn-genes) have been determined by hybridization of radioactivity labelled tRNAs to cpDNA fragments (15).

Restriction endonuclease fragments of cpDNA from these species have been cloned in bacterial vectors and used to identify additional genes on the cpDNAs. The cloned fragments were employed both in coupled transcriptiontranslation assays and for hybrid-selection of mRNAs followed by in vitro translations to identify the structural genes for the following chloroplast polypeptides: The large subunit of ribulosebisphosphate carboxylase (rbcL) (32, 54), ATP synthetase $\mathrm{CF}_{1}$ subunit $\alpha$ (atpA) (50), subunit $\beta$ and subunit $\varepsilon$ (atpB/atpE) $(27,53)$, cytochrome $f$ (pet) and the subunitlII of ATP synthetase $\mathrm{CF}_{0}(\operatorname{atpH})(21)$, and one light inducible 32,000 dalton thylakoid protein (psbA) (6). The nucleotide sequences for several of these genes have been or are currently being established $(42,55)$. The above types of genes are limited to products for which antibodies are available or to genes which are expressed in non-homologous systems.

In vitro hybridizations between chloroplast RNA and chloroplast DNA has indicated that $40-60 \%$ of the chloroplast genome is expressed as transcripts $(6,33)$. This would correspond to transcription of about one strand of the genome. In an average genome of 140,000 basepairs, 15,000 can be assumed to encode rRNAs and tRNAs, while 125,000 basepairs are available to accomodate genes for proteins, with an upper total limit of 30,000 to 40,000 amino acids. If an average protein contains 300 residues, a coding capacity for more than 100 proteins is to be expected. In order to find out if such a large number of transcripts indeed are made, I have used 21 mapped restriction endonuclease fragments comprising $80 \%$ of the barley cpDNA as hybridization probes for electrophoretically separated chloroplast RNA molecules. For distinction of transcripts made in the dark, in the light or under both conditions the chloroplast RNA was isolated from dark grown seedlings and from seedlings greened for 8 hours.

\section{MATERIALS AND METHODS}

\subsection{Chemicals and enzymes}

All chemicals used were analytical grade. Phenol was freed of impurities by distillation. Buffer containing 5 m-guanidinium thiocyanate (Fluka, Buchs, Switzerland) was sterilized by passing through disposable $0.22 \mu \mathrm{m}$ filters (Millipore, Bedford, Ma., USA). Formamide AnalAR (BDH, Poole, England) was deionized with AG501x8 from Bio-Rad (Richmond, Cal., USA). $37 \%$ formaldehyde AnalAR was also from BDH. Agarose for gel electrophoresis was from Sigma, St. Louis, Mo., USA. The use of Seakem HGT agarose from Marine Colloids, Rockland, Me., USA will be specified in the text. Nitrobenzyloxy-methylpyridinium chloride (NBPC) was kindly provided by professor $\mathrm{K}$. MARCKER. DNase I (DN100) lysozyme and bovine serum albumin was purchased from Sigma and pronase from Calbiochem, S. Diego, $\mathrm{Cal}$., USA. The pronase was dissolved in $\mathrm{H}_{2} \mathrm{O}$ at a concentration of $5 \mathrm{mg} / \mathrm{ml}$ and self-digested for two hours at $37^{\circ} \mathrm{C}$ before use. The restriction endonucleases HindIII, PstI, SalI, EcoRI, BamH I and PvuII were generally from Boehringer, Mannheim, W. Germany. Sall and PvuII, obtained from New England Biolabs, Beverly, Ma., USA and BamH 1 from Bethesda Research Laboratories, Rockville, Md., USA was also used occasionally. For DNA/DNA ligations, T4 DNA ligase from New England Biolabs was used. 
DNA polymerase I was from Boehringer. All DNA modifying enzymes were used according to the instructions provided by the companies, unless other conditions are described.

\subsection{Plant material}

Barley plastid nucleic acids were isolated from seedlings of Hordeum vulgare L. var Bonus. Seeds were germinated and grown in moist vermiculite for six days in the dark at $20^{\circ} \mathrm{C}$. Before plastid DNA isolation, seedlings corresponding to about one $\mathrm{kg}$ of leaf material were illuminated in white light (2400 lux) overnight. For plastid RNA extraction, etiolated seedlings corresponding to about $100 \mathrm{~g}$ of leaf material were used either directly or after illumination with white light ( 2400 lux) for 2, 4, 6, 8, 10 and 15 hours. In one experiment the seedlings were transferred back into the dark for 13 hours after 2 hours of illumination, and thereafter used for RNA extraction. In all experiments the uppermost 5-8 $\mathrm{cm}$ of the seedling leaves were used.

\subsection{Preparation of developing plastids}

The procedure for isolating barley plastids from seedlings was a slight modification of that used by Kolodner and Tewari $(25,26)$. Homogenization was performed in buffer $\mathrm{A}: 0.3 \mathrm{M}$ mannitol, $50 \mathrm{~mm}$-Tris-HCl pH 8.0, 3 mM-EDTA, $10 \mathrm{~mm}$-2-mercaptoethanol and $1 \mathrm{mg} / \mathrm{ml}$ bovine serum albumin. Batches of $100 \mathrm{~g}$ of detached seedling leaves, precooled on ice, were homogenized in the modified Braun homogenizer (23) with $500 \mathrm{ml}$ of icecold buffer A. Homogenization was performed with three five-second bursts at maximal speed. A crude filtration was made through one layer of miracloth (Calbiochem) followed by an additional filtration through four layers of miracloth. All operations were at $0{ }^{\circ} \mathrm{C}-4$ ${ }^{\circ} \mathrm{C}$. For the etiolated tissue, operations were performed in a dark room under green safelight.

For chloroplast DNA isolation, five such homogenates were combined before centrifugation (GS-3, Sorvall, 6,000 rpm, $4 .{ }^{\circ} \mathrm{C}, 20$ minutes). During the first centrifugation another five homogenates were made. After miracloth filtrations, these replaced the supernatants of the first centrifugation. All plastids were subsequently pelleted by a second spin. After decanting the supernatants, pellets were resuspended in buffer
A $\left(0{ }^{\circ} \mathrm{C}\right)$ with the help of a soft paintbrush. A total volume of $100 \mathrm{ml}$ of plastid suspension was obtained. This could now be used for further treatment before DNA extraction (cf. section 2.4.).

For plastid RNA extraction the filtrate of one homogenate of $100 \mathrm{~g}$ of seedling leaves was centrifuged in four GSA tubes (Sorvall, 6,000 rpm, 4 ${ }^{\circ} \mathrm{C}, 10$ minutes). Supernatants were discarded whereafter the pellets were resuspended to a total volume of $10 \mathrm{ml}$ with buffer $\mathrm{A}\left(0^{\circ} \mathrm{C}\right)$. RNA was extracted from these plastids after another step of purification (cf. section 2.5.).

\subsection{Extraction of plastid DNA}

To crush or remove contaminating nuclei, the $100 \mathrm{ml}$ of plastid suspension was filtered through a sheet of $31 \mu \mathrm{m}$ nylon cloth into an Erlenmeyer flask placed in ice. One $\mathrm{ml}$ of $1 \mathrm{M}-\mathrm{MgCl}_{2}$ was added. Ten mg of DNasel, which had been preincubated in $2 \mathrm{ml}$ of $5 \mathrm{~mm}-\mathrm{MgCl}_{2}, 50 \mathrm{~mm}$-Tris- $\mathrm{HCl}$ $\mathrm{pH} 8.0$, was added to the flask. Most of the free DNA was degraded during a one hour incubation at $0{ }^{\circ} \mathrm{C}$. The suspension was occasionally gently swirled. Subsequently the suspension was evenly distributed on top of six sucrose cushions, each consisting of $200 \mathrm{ml}$ of $0.5 \mathrm{M}$-sucrose, 50 mM-Tris- $\mathrm{HCl}$ pH 8.0, 20 mm-EDTA whereafter the plastids were pelleted (GSA, Sorvall, 6,000 rpm, $4{ }^{\circ} \mathrm{C}, 20$ minutes) through the cushions. Supernatants were discarded and the plastids resuspended to a total volume of $200 \mathrm{ml}$ with buffer B (0.3 M-sucrose, $50 \mathrm{~mm}$-Tris- $\mathrm{HCl} \mathrm{pH} 8.0,20$ $\mathrm{mm}$-EDTA). The plastids were repelleted as described above. This resuspension-repelleting step was repeated two times. Hereby most remaining DNA and DNaseI activity in the medium surrounding the plastids was removed. The last pellet was resuspended in $20 \mathrm{ml}$ of buffer $\mathrm{B}\left(0^{\circ} \mathrm{C}\right)$. Five $\mathrm{ml}$ of a $10 \%(\mathrm{w} / \mathrm{v}) \mathrm{Na}-\mathrm{N}$-lauroyl-sarcosinate solution and $0.3 \mathrm{ml}$ of the selfdigested pronase was added. This mixture was incubated at $37^{\circ} \mathrm{C}$ for one hour with gentle shaking. During this process the plastids were lysed. Meanwhile 200 $\mathrm{ml}$ of redistilled phenol was equilibrated and saturated with $0.1 \mathrm{M}$-Tris- $\mathrm{HCl} \mathrm{pH} \mathrm{8.0.} \mathrm{After} \mathrm{plastid}$ lysis, the suspension was extracted four to six times with the buffer-equilibrated phenol. Phase separation was performed in polypropylene centrifuge tubes in the HB-4 rotor (Sorvall, 10,000 
rpm, $20{ }^{\circ} \mathrm{C}, 10$ minutes). The last upper phase was pink and slightly turbid. This chloroplast DNA containing solution was distributed evenly in four siliconized corex centrifuge tubes, whereafter 2.5 volumes of ethanol $\left(-20^{\circ} \mathrm{C}\right)$ was added to each. Nucleic acids precipitated overnight at $-20{ }^{\circ} \mathrm{C}$, followed by pelleting in the Sorvall (SS$34,10,000 \mathrm{rpm}, 0{ }^{\circ} \mathrm{C}, 10$ minutes). The pellets were washed with $65 \%$ ethanol $\left(-20^{\circ} \mathrm{C}\right)$ and repelleted. After removal of the supernatants, the pellets were dried for 30 minutes in open air and then redissolved in one $\mathrm{ml}$ of $50 \mathrm{~mm}$-Tris- $\mathrm{HCl}$ pH 8.0, 20 mm-EDTA. The plastid nucleic acids were now spun through sucrose gradients in the following way: Four $13 \mathrm{ml}$ gradients of 5-30\% sucrose were formed in SW40 cellulose nitrate tubes. The gradients contained $100 \mathrm{~mm}-\mathrm{Tris}-\mathrm{HCl}$ pH 8.0, 10 mm-EDTA. A fourth of the nucleic acid solution was placed on top of each gradient. These were centrifuged for 14 hours at 21,000 rpm and $4{ }^{\circ} \mathrm{C}$ in the $S W 40$ of a Beckman ultracentrifuge. Subsequently, all but the bottom four $\mathrm{cm}$ of the gradients were removed and replaced by $10 \mathrm{~mm}$-Tris- $\mathrm{HCl} \mathrm{pH} \mathrm{8.0,1} \mathrm{mm-EDTA.} \mathrm{Ultra-}$ centrifugation was continued for 16 hours at $35,000 \mathrm{rpm}$ and $4^{\circ} \mathrm{C}$. The sucrose gradients were then poured into a beaker by rapid flipping over the tubes. This left a DNA pellet in the bottom of the tubes. Each pellet was carefully redissolved in $100 \mu 1$ of $10 \mathrm{~mm}$-Tris- $\mathrm{HCl} \mathrm{pH} 8.0,1 \mathrm{~mm}$-EDTA. The four solutions were combined and could now be used for analyses. The yield and purity of the DNA was estimated by measurement of absorbance at 260 and $280 \mathrm{~nm}$. An absorbance of 1.0 at $260 \mathrm{~nm}$ in a $1 \mathrm{~cm}$ pathway is assumed to correspond to $50 \mu \mathrm{g} / \mathrm{ml}$. The DNA was stored at $4{ }^{\circ} \mathrm{C}$.

\subsection{Extraction of RNA from developing plastids}

Crude plastids from $100 \mathrm{~g}$ of etiolated or developing seedlings, suspended in $10 \mathrm{ml}$ of buffer A, were filtered through small $31 \mu \mathrm{m}$ nylon filters. The filtrate was then layered on a $200 \mathrm{ml}$ sucrose cushion, whereafter the plastids were pelleted like before (cf. section 2.4.). The pellet was resuspended in two $\mathrm{ml}$ of buffer $\mathrm{B}\left(0^{\circ} \mathrm{C}\right)$ and transferred to an SS-34 polypropylene centrifuge tube. In order to rupture plastids and immediately inactivate contaminating ribonuclease activity, $10 \mathrm{ml}$ of $5 \mathrm{M}$-guanidinium thiocyanate,
50 mm-Tris- $\mathrm{HCl} \mathrm{pH} \mathrm{7.5,} 10$ mm-EDTA, 5\% 2mercaptoethanol was added together with $8 \mathrm{ml}$ of $10 \% \mathrm{Na}-\mathrm{N}$-lauroyl-sarcosinate and $3 \mathrm{~g}$ of $\mathrm{CsCl}$. After careful mixing, denatured protein was removed by centrifugation (Sorvall, 15,000 rpm, 4 ${ }^{\circ} \mathrm{C}, 20$ minutes). Four $\mathrm{ml}$ fractions of the yellow to green supernatants were loaded on one $\mathrm{ml}$ cushions of $5.7 \mathrm{M}-\mathrm{CsCl}, 100 \mathrm{~mm}$-EDTA pH 7.5 in SW50.1 polyallomer centrifuge tubes. The RNA was spun through the $\mathrm{CsCl}$-cushions in the SW50.1 rotor in a Beckman ultracentrifuge (37,000 rpm, $20^{\circ} \mathrm{C}, 18$ hours). Supernatants were discarded and the glass clear pellets rapidly washed with $3 \mathrm{M}$-Na-acetate $\mathrm{pH} 5.5\left(0{ }^{\circ} \mathrm{C}\right)$. All salt solution was removed and the RNA dissolved in two $\mathrm{ml}$ of $10 \mathrm{~mm}$-Tris- $\mathrm{HCl} \mathrm{pH} \mathrm{7.5.} \mathrm{The}$ RNA was further cleaned by precipitation with 2.5 volumes of ethanol. RNA was collected by centrifugation, dried in a stream of nitrogen and subsequently dissolved in sterile $\mathrm{H}_{2} \mathrm{O}$ at a concentration of $3 \mathrm{mg} / \mathrm{ml}$ as estimated by absorbance at $260 \mathrm{~nm}$. An absorbance of 1.0 was assumed to correspond to a concentration of 40 $\mu \mathrm{g} / \mathrm{ml}$. The RNA preparations were stored at -20 ${ }^{\circ} \mathrm{C}$ until required for analysis. Centrifuge tubes and all buffers, except the guanidinium thiocyanate, were autoclaved and all glassware was heat sterilized at $240{ }^{\circ} \mathrm{C}$ for at least two hours before use.

\subsection{Concentrating DNA and change of assay conditions}

When new experimental steps or new assay conditions were required, ethanol precipitations of the nucleic acids were employed. The following general procedure was used: Addition of one tenth volume of $3 \mathrm{~m}-\mathrm{Na}$-acetate $\mathrm{pH} 7.0$ and of 2.5 volumes of $96 \%$ ethanol $\left(-20^{\circ} \mathrm{C}\right)$. The precipitation mixtures were stored at $-20{ }^{\circ} \mathrm{C}$ overnight or at $-70{ }^{\circ} \mathrm{C}$ for $30-60$ minutes. In case of large volume precipitations, siliconized $15 \mathrm{ml}$ or $30 \mathrm{ml}$ corex tubes were used. Precipitated material was collected by centrifugation (SS-34, Sorvall, $10,000 \mathrm{rpm}, 0^{\circ} \mathrm{C}, 10$ minutes). Collection of nucleic acids on a small scale was performed in microcentrifuge tubes in an Eppendorf microcentrifuge placed in a cold room. After centrifugations, supernatants were discarded and nucleic acid pellets washed with $65 \%$ ethanol $\left(-20^{\circ} \mathrm{C}\right)$. Pellets were recollected by centrifuga- 
tion as before. The pellets were dried in a stream of nitrogen or in an evacuated desiccator. At last the nucleic acids were redissolved to accomodate the subsequent conditions.

\subsection{Cloning of chloroplast DNA}

For cloning of chloroplast DNA (cpDNA) fragments, the restriction endonucleases HindIII and PstI were used. HindIII fragments were ligated into the HindIII site in the tetracycline-resistance gene of pBR322 and PstI fragments were ligated into the PstI site in the ampicillinresistance gene of pBR325 (7). In both cases, cpDNA and pBR were mixed in a 1:1 molar ratio before restriction. A total of $5 \mu \mathrm{g}$ of DNA was digested in $50 \mu \mathrm{l}$. After two hours of digestion, the mixtures were heated to $65^{\circ} \mathrm{C}$ for five minutes. As a control, $10 \mu \mathrm{l}$ of the digestion assay was removed for gel electrophoresis. The residual 40 $\mu \mathrm{l}$ were diluted to $100 \mu \mathrm{l}$ with $40 \mu \mathrm{l}$ of $\mathrm{H}_{2} \mathrm{O}, 10 \mu \mathrm{l}$ 4 mM-ATP and $10 \mu$ of ten times concentrated ligase buffer. Between 30 and 40 units of T4 DNA ligase in $0.1 \mu \mathrm{l}$ was added. Ligation was carried out for four to six hours at $22^{\circ} \mathrm{C}$. After ligation, $25 \mu \mathrm{l}$ was removed for gel electrophoresis. The residual amount of ligated DNA was precipitated and redissolved in $100 \mu \mathrm{l}$ of transformation buffer ( $20 \mathrm{~mm}$-Tris- $\mathrm{HCl} \mathrm{pH}$ 8.0, $20 \mathrm{~mm}-\mathrm{NaCl}, 1 \mathrm{~mm}$-EDTA). Transformation into competent Escherichia coli HB 101 (recA; $\mathrm{mt}$ ) was performed as described by COHEN et al. (13). Transformants containing recombinant plasmids were grown and selected on growth media containing the appropriate antibiotics. Samples of pBR322 and pBR325 were kindly provided by dr. S. HolmberG. E. coli HB 101 is in general circulation in the department. When containing recombinant plasmids, E. coli was handled under Pl laboratory conditions (19).

\subsection{Screening recombinant plasmids and preparation of plasmid DNA}

Recombinant plasmids were isolated by the small scale procedure described by BIRNBOIM and Doly (5). Plasmids isolated from $5-10 \mathrm{ml}$ of liquid culture, contained in $100 \mu \mathrm{l}$ of $10 \mathrm{~mm}$-Tris$\mathrm{HCl} \mathrm{pH} \mathrm{8.0,} 1 \mathrm{~mm}$-EDTA, were further purified by centrifugation through $0.4 \mathrm{ml}$ beds of Sephadex G-50 equilibrated in $10 \mathrm{~mm}$-Tris- $\mathrm{HCl}$ pH 8.0, 1 mm-EDTA. Aliquots of recombinant
pBR322-derived plasmids were then digested with HindIII, whereafter gel electrophoresis was run with HindIII digested cpDNA included as a marker.pBR325-derived plasmids were screened in a similar way, except that PstI was used. Electrophoresis was run in $0.7 \%$ agarose gels. Electrophoresis buffer was $90 \mathrm{~mm}$-Tris-borate, 20 mM-EDTA, pH 8.3. Gels contained $1 \mu \mathrm{g}$ of ethidium bromide per ml. DNA fragments in the gels were visualized with transilluminating UVlight and photographed.

Recombinant plasmids containing cpDNA fragments were subsequently prepared by a 50 fold upscaled version of the BIRNBOIM and DOLY procedure (5). The bacterial nucleic acids obtained this way were separated in $\mathrm{CsCl}$-gradients in 50Ti cellulose nitrate tubes. Dried nucleic acids were dissolved in $8 \mathrm{ml}$ of $0.15 \mathrm{M}-\mathrm{NaCl}$, $0.015 \mathrm{~m}$-Na-citrate, $1 \mathrm{~mm}$-EDTA pH 7.0. Eight $\mathrm{g}$ of $\mathrm{CsCl}$ was added and ethidium bromide was included at a final concentration of $0.2 \mu \mathrm{g} / \mathrm{ml}$. Gradients were formed by $48-60$ hours of centrifugation at $37,000 \mathrm{rpm}$ and $18{ }^{\circ} \mathrm{C}$ in a Beckman ultracentrifuge. The plasmid bands were collected under UV-light and ethidium bromide removed by six extractions with equal volumes of $n$-butanol. The plasmids were then dialyzed for 24 hours against $10 \mathrm{~mm}$-Tris- $\mathrm{HCl} \mathrm{pH} 8.0,1$ mM-EDTA. The DNA was precipitated and redissolved in $10 \mathrm{~mm}$-Tris- $\mathrm{HCl} \mathrm{pH} 8.0,1 \mathrm{~mm}-$ EDTA at a concentration of $1 \mathrm{mg} / \mathrm{ml}$ and was now ready for analyses. The maize chloroplast DNA recombinant plasmid pZmC3711 was prepared in this manner also.

\subsection{Restriction endonuclease analysis of cpDNA and recombinant plasmids}

Barley cpDNA was digested with the restriction endonucleases PstI, SalI and PvulI. Aliquots containing two $\mu \mathrm{g}$ of digested DNA were run on $0.7 \%$ agarose gels (cf. section 2.8 .). The digestion patterns were compared to published data for similar digestions of the wheat cpDNA (9) and maize cpDNA $(2,35)$. The similarity of the digestion patterns was a guideline to establish the physical structure of the barley chloroplast genome.

Recombinant PstI-plasmids containing nine of eleven fragments were mapped with the aid of single, double and triple digestions using com- 
binations of the four restriction endonucleases PstI, SalI, PvuII and HindIII. During electrophoresis, standardized fragments from $\lambda$ DNA digested with EcoRI, HindIII and EcoRI + HindIII were used as size markers. Markers were also made from the 5.9 kilobasepair (kbp) pBR325, which was digested in a fashion similar to the pBR325-derived recombinant plasmids. This helped to locate pBR325-derived fragments in digests of the recombinant molecules, when electrophoresed on the same gel.

The apparent similarity in the structure of barley cpDNA with that of wheat and maize, and the physical maps of the Pstl-plasmids, allowed the construction of a preliminary map of the barley cpDNA. These data were further confirmed by control for consistency between the map and the band patterns obtained with single, double and triple digestions of intact cpDNA using combinations of PstI, SalI and PvulI according to the procedures described in (17). Sites for these three enzymes were also located in some of the pBR322-derived HindIII plasmids. Additional allocation of cloned HindIII fragments were obtained by comparison of sizes and RNA-hybridization patterns (cf. section 2.14. and 3.6.) with those of the HindIII fragments isolated from the PstI plasmids. At last, consistency between the location of HindIII sites and the band pattern obtained after HindIII digestion of intact cpDNA was required.

The gene for the large subunit of RuBPCase was located in the following way: Samples of two $\mu \mathrm{g}$ of barley cpDNA were digested with HindIII, SalI, BamHI and EcoRI. The fragments were separated by electrophoresis on $0.8 \%$ Seakem agarose gels. Subsequently, the separated fragments were transferred to nitrocellulose filters (Millipore) as described by SOUTHERN (43). Two sets of filters were prepared of which one was without the Sall fragments. The filters were hybridized with two different radioactive probes according to the procedure described by DENHARDT (16). The filter with the four sets of fragments was hybridized with $1 \mu \mathrm{g}$ of nick translated $\mathrm{pZmC} 3711$ whereas the other filter was hybridized with a probe prepared by nick translation of $0.2 \mu \mathrm{g}$ of a 567 basepair Pstl fragment from within the $\mathrm{rbcL}$ region. BamHI and EcoRI sites were mapped in the two PstI plasmids shar- ing the barley rbcL gene. These experiments included single, double and triple digestions in combinations with HindIII and PstI as well as subdigestions of specific fragments isolated from these plasmids (cf. section 2.10. and 3.2).

\subsection{Isolation of individual fragments}

To isolate selected restriction endonuclease fragments of the barley cpDNA, 10-20 $\mu \mathrm{g}$ of the different PstI plasmids were digested with combinations of the appropriate restriction endonucleases. The digested plasmids were electrophoresed on $0.7 \%$ Seakem agarose gels. After separation, slices containing the wanted fragments were excized from the gels and subsequently the DNA was electroeluted in dialysis tubing covered wells in another agarose gel, according to WIENAND et al. (51). The eluted DNA was precipitated and redissolved in $100 \mu 10$ mm-Tris- $\mathrm{HCl} \mathrm{pH} 8.0,1$ mm-EDTA. The solutions were then passed over Sephadex G-50 beds as previously described. Homogeneity and yield of the fragments was checked by agarose gel electrophoresis of aliquots of the Sephadex filtrates.

Inserts of the HindIII plasmids were prepared in a similar way, after digestion of 5-10 $\mu \mathrm{g}$ of the selected plasmids with HindIII. The 567 bp Pstl fragment from $\mathrm{pZmC} 3711$ was obtained in this manner also after digestion of $10 \mu \mathrm{g}$ of plasmid with PstI.

DNA fragments thus purified could be used for nick translation and hybridization (cf. sections 2.13 and 2.14) or for subdigestions with other enzymes.

\subsection{Electrophoresis of RNA}

For electrophoresis of RNA on denaturing agarose gels, $2 \mu l$ aliquots of RNA preparations (cf. section 2.5.) was combined with $3.5 \mu \mathrm{l}$ of $37 \%$ formaldehyde. Also added was $10 \mu \mathrm{l}$ of deionized formamide, $2 \mu \mathrm{l} 0.1 \%(\mathrm{w} / \mathrm{v})$ bromphenolblue, $2 \mathrm{ml}$ of 10 times concentrated electrophoresis buffer and $0.5 \mu \mathrm{l}$ of $\mathrm{H}_{2} \mathrm{O}$. Before electrophoresis, samples were heated to $60^{\circ} \mathrm{C}$ for 15 minutes followed by rapid cooling in an ethanol/ ice-bath $\left(-10^{\circ} \mathrm{C}\right)$. Gels for electrophoresis consisted of $1.5 \%$ Seakem agarose, $6 \%$ formaldehyde and $20 \mathrm{~mm}-\mathrm{Na}$-morpholinopropane sulphonate pH 7.0, 5 mm-Na-acetate, 1 mm-EDTA (electrophoresis buffer) (31). After loading of the 
cooled samples, electrophoresis was run until the bromphenolblue tracking dye had migrated to about $1 \mathrm{~cm}$ from the bottom of the gel. Gels were subsequently washed in a stream of cold tap water for removal of excess formaldehyde (20-30 minutes).

The RNA could now be stained for photography. This was performed in $0.1 \mathrm{M}-\mathrm{Tris}-\mathrm{HCl} \mathrm{pH}$ 9.0 containing ethidium bromide $(1 \mu \mathrm{g} / \mathrm{ml})$ for 30 minutes. Destaining was also in $0.1 \mathrm{M}$-Tris$\mathrm{HCl} \mathrm{pH} \mathrm{9.0} \mathrm{(30-60} \mathrm{minutes).} \mathrm{If} \mathrm{gels} \mathrm{were} \mathrm{to} \mathrm{be}$ used for transfer of RNA to hybridization filters staining was avoided.

For calibration of the gels, the following RNA markers were used: Total RNA from E. coli, barley endosperm RNA (courtesy of drs. E. Hopp and A. BRANDT) and globin mRNA (New England Nuclear, Boston, Ma., USA).

\subsection{Preparation of RNA-paper for hybridization}

Modification of Whatman 540 filter paper (Whatman, Maidstone, Kent, England) into nitrobenzyloxy-methyl-(NBM-) paper and its subsequent modification into diazobenzyloxymethyl- (DBM-) paper, was performed as described by ALwINE et al. (1). RNA-gels (cf. section 2.11.) for blotting were immersed into $50 \mathrm{~mm}$ $\mathrm{NaOH}$ for 60 minutes $\left(20^{\circ} \mathrm{C}\right)$, whereby partial RNA-degradation was obtained. The gels were subsequently neutralized in $1 \mathrm{M}$-Na-acetate $\mathrm{pH}$ 4.0 (two exchanges, each for 15 minutes).

The RNA was then blotted onto freshly prepared DBM-paper $(1,49)$ employing $1 \mathrm{M}$-Na-acetate $\mathrm{pH} 4.0$ as the blotting agent. Blotting was overnight at room temperature. The RNA-filters were then prehybridized in plastic boiling bags in a shaking waterbath at $40^{\circ} \mathrm{C}$ for $6-12$ hours. Conditions were: $50 \%(\mathrm{v} / \mathrm{v})$ deionized formamide, $0.75 \mathrm{M}-\mathrm{NaCl}, 75 \mathrm{~mm}-\mathrm{Na}$-citrate, $50 \mathrm{~mm}-\mathrm{Na}$ phosphate $\mathrm{pH} 6.5,0.2 \%(\mathrm{w} / \mathrm{v}) \mathrm{Na}$-dodecylsulphate, $0.02 \%(\mathrm{w} / \mathrm{v})$ bovine serum albumin, $0.02 \%(\mathrm{w} / \mathrm{v})$ ficoll, $0.02 \%(\mathrm{w} / \mathrm{v})$ polyvinylpyrrolidone, $1 \%(\mathrm{w} / \mathrm{v})$ glycine and $0.5 \mathrm{mg} / \mathrm{ml}$ of sonicated, phenol-extracted, heat-denatured salmon sperm DNA (hybridization grade).

\subsection{Nick translation of plastid DNA sequences}

In vitro incorporation of 32P-labelled deoxynucleotides into DNA was performed essentially as described by RigBY et al. (38). The radioactive component was triethylammonium- $\alpha$-32P-deoxyadenosine-5'-triphosphate at a specific activity of $400 \mathrm{Ci} / \mathrm{mmol}$ (NEG-012A, New England Nuclear, Boston, Ma., USA). Assay mixture concentrations of the three cold deoxynucleosidetriphosphates were $0.5 \mathrm{~mm}$ for each of dCTP, dGTP and dTTP. The nick translations were performed at $14{ }^{\circ} \mathrm{C}$.

For intact plasmids conditions were $5 \mathrm{ng} / \mu \mathrm{l}$ DNA, $1 \mu \mathrm{Ci} / \mu \mathrm{l}$ of $32 \mathrm{P}$-dATP, and $0.05 \mathrm{u} / \mu \mathrm{l}$ of DNApolymerase I for two hours. For fragments conditions were $2 \mathrm{ng} / \mu \mathrm{l}$ DNA, $1 \mu \mathrm{Ci} / \mu \mathrm{l}$ of $32 \mathrm{P}$ $\mathrm{dATP}$ and $0.1 \mathrm{u} / \mu \mathrm{l}$ of DNApolymerase I for only one hour. Incorporation was measured as TCAprecipitable counts per minute. Precipitations over 10 minutes at $0{ }^{\circ} \mathrm{C}$ contained $1 \mu$ assay mix, $50 \mu \mathrm{g}$ of salmon sperm DNA and $1 \mathrm{ml}$ of $10 \%$ trichloroacetic acid. Precipitated DNA was collected on glassfiber filters (Schleicher and Schull, Keene, N.H., USA). The filters were counted in vials also containing $5 \mathrm{ml}$ of Dimilume scintillant (Packard, Downers Grove, Ill., USA) employing the 32P-channel of a Beckman liquid scintillation counter. Nick translations were ended by addition of $5 \mu \mathrm{l}$ of $0.5 \mathrm{M}$-EDTA pH 7.5. Free nucleotides and oligonucleotides were removed by two precipitations with two volumes of ethanol after the addition of a tenth volume of $3 \mathrm{M}-\mathrm{Na}$-acetate and $10 \mu \mathrm{g}$ of hybridization grade salmon sperm DNA. The second precipitation was performed after resuspension of the first pellet in $0.3 \mathrm{~m}$-Na-acetate (cf. section 2.6.).

\subsection{Hybridization of radioactive DNA-probes to filterbound RNA}

Conditions for hybridization of nick translated DNA to filterbound RNA were essentially as described for the prehybridization (cf. section 2.12.), except for the following changes: Concentration of salmon sperm DNA was reduced to $0.1 \mathrm{mg} / \mathrm{ml}$, glycine was omitted and dextran sulphate (Pharmacia, Uppsala, Sweden) was added to a final concentration of $10 \%(w / v)(49)$. Precipitated, dried radioactive probe was dissolved in a fraction of the hybridization solution and subsequently denatured by heating to $95^{\circ} \mathrm{C}$ for five minutes. The denatured probe was added to the residual amount of hybridization solution, 
which had been preheated to $60{ }^{\circ} \mathrm{C}$. The hybridization filter was moved to a new plastic boiling bag, the hybridization mixture was added and the plastic bag sealed. Hybridization was carried out in a shaking waterbath at $44^{\circ} \mathrm{C}$ over a period of 16-20 hours. The amount of probe used correspond to about 50-100 ng per lane on the filter. One $\mathrm{ml}$ of hybridization mixture was used per lane. The specific activity of the DNA was generally $5-10 \times 10^{7} \mathrm{cpm}$ per $\mu \mathrm{g}$ and $2-5 \times 10^{7} \mathrm{cpm}$ per $\mu \mathrm{g}$ for fragments. After hybridization, filters were washed as described by ALwINE et al. (1) and subsequently dried and covered with plastic wrap. Autoradiography on Kodak RP X-ray film employing intensifying screens was carried out at $-70{ }^{\circ} \mathrm{C}$.

\section{RESULTS AND DISCUSSION}

\subsection{The physical structure of the barley chloroplast genome}

In Figure 1 the PvuII/SalI/PstI-map obtained for barley cpDNA is presented and compared to the Pvull/SalII-map of maize (35) and to the PstI/SalI-map of wheat cpDNA (9). When barley cpDNA is restricted with Sall fourteen fragments are obtained with the molecular sizes in kbp listed in Figure 1 and Table I. They range from $28.1 \mathrm{kbp}$ to $0.8 \mathrm{kbp}$. It is apparent that 13 of
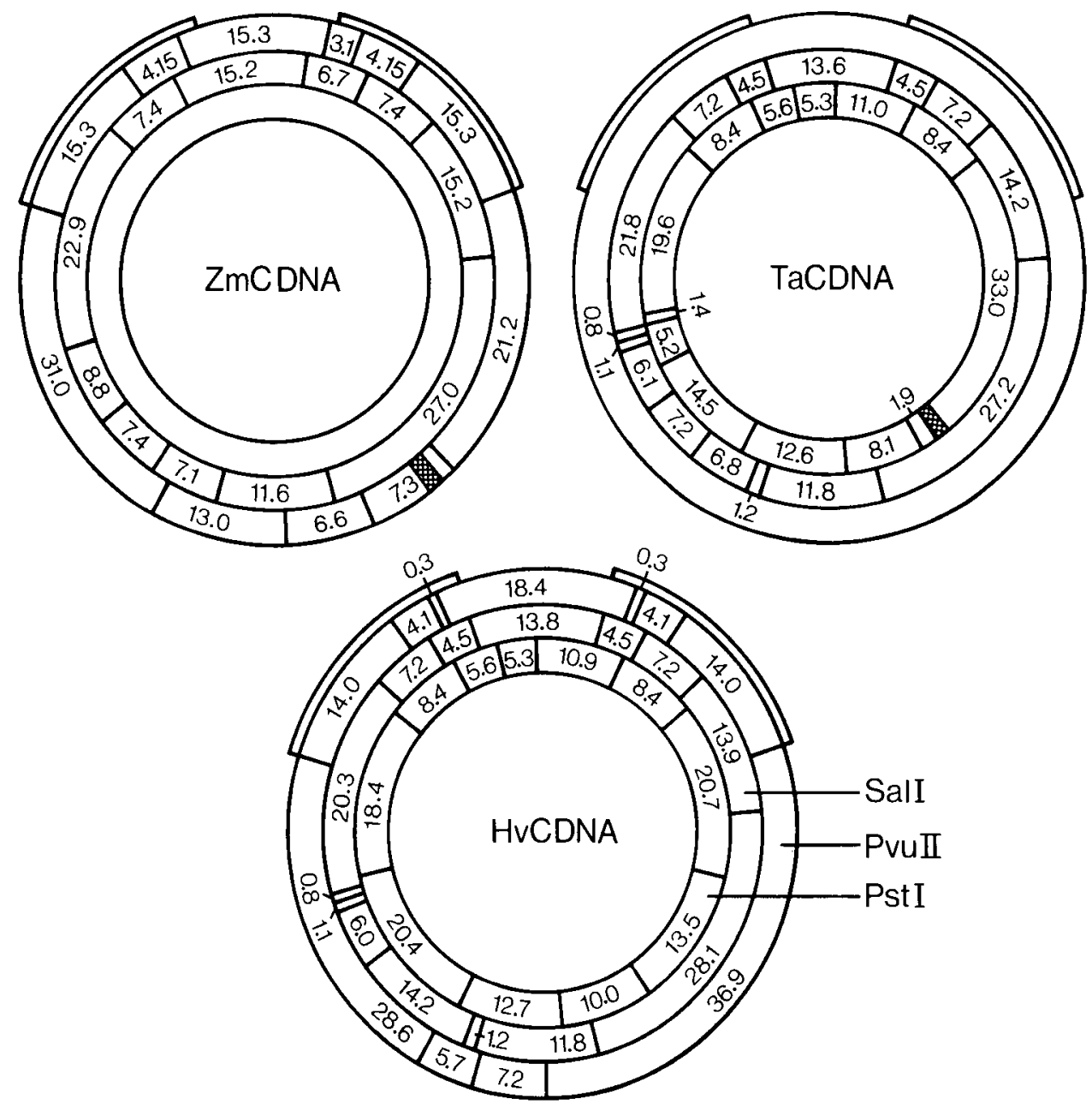

Figure 1. Comparison of restriction endonuclease maps of the chloroplast genomes of maize ( $\mathrm{ZmCDNA}$ ), wheat (TaCDNA) and barley (HvCDNA).

The circles show the fragments obtained by digestion with PvuII (outer circle), SalI (middle circle) and PstI (inner circle). Fragment sizes are given in kilobasepairs. The cross hatched areas indicate the location of the gene for the large subunit of ribulose bisphosphate carboxylase. 
the fragments have very similar sizes to 13 wheat Sall fragments. If the barley fragments are arranged in the map order established for wheat the fourteenth fragment of barley with a size of $14.2 \mathrm{kbp}$ has to be placed at 7 o'clock between the $1.2 \mathrm{kbp}$ and the $6.0 \mathrm{kbp}$ Sall fragments. It is then seen that in wheat one extra Sall site is present giving rise to the 6.8 and $7.2 \mathrm{kbp}$ fragments located in this position.

Cleavage of barley cpDNA with PstI yields 11 fragments with the sizes given in Figure 1 and Table I. Comparison with the map of wheat reveals that seven barley and wheat PstI fragments are homologous in size. The barley $20.4 \mathrm{kbp}$ PstI fragment at 80 'clock is represented in wheat by three fragments of $14.5,5.2$ and $1.4 \mathrm{kbp}$. On the other hand the $33.0 \mathrm{kbp}$ fragment of wheat corresponds to a 20.7 and a $13.5 \mathrm{kbp}$ fragment in barley. The neighboring barley fragment of 10.0 $\mathrm{kbp}$ is split in wheat into an 8.1 and $1.9 \mathrm{kbp}$ fragment.

The deviation of the barley map from that of wheat by fragment size comparison could be substantiated by mapping of restriction fragments in the following way. Nine of the eleven Pstl restriction fragments have been cloned in pBR325. These are presented with their clone numbers in Table I and Figure 2. Each plasmid

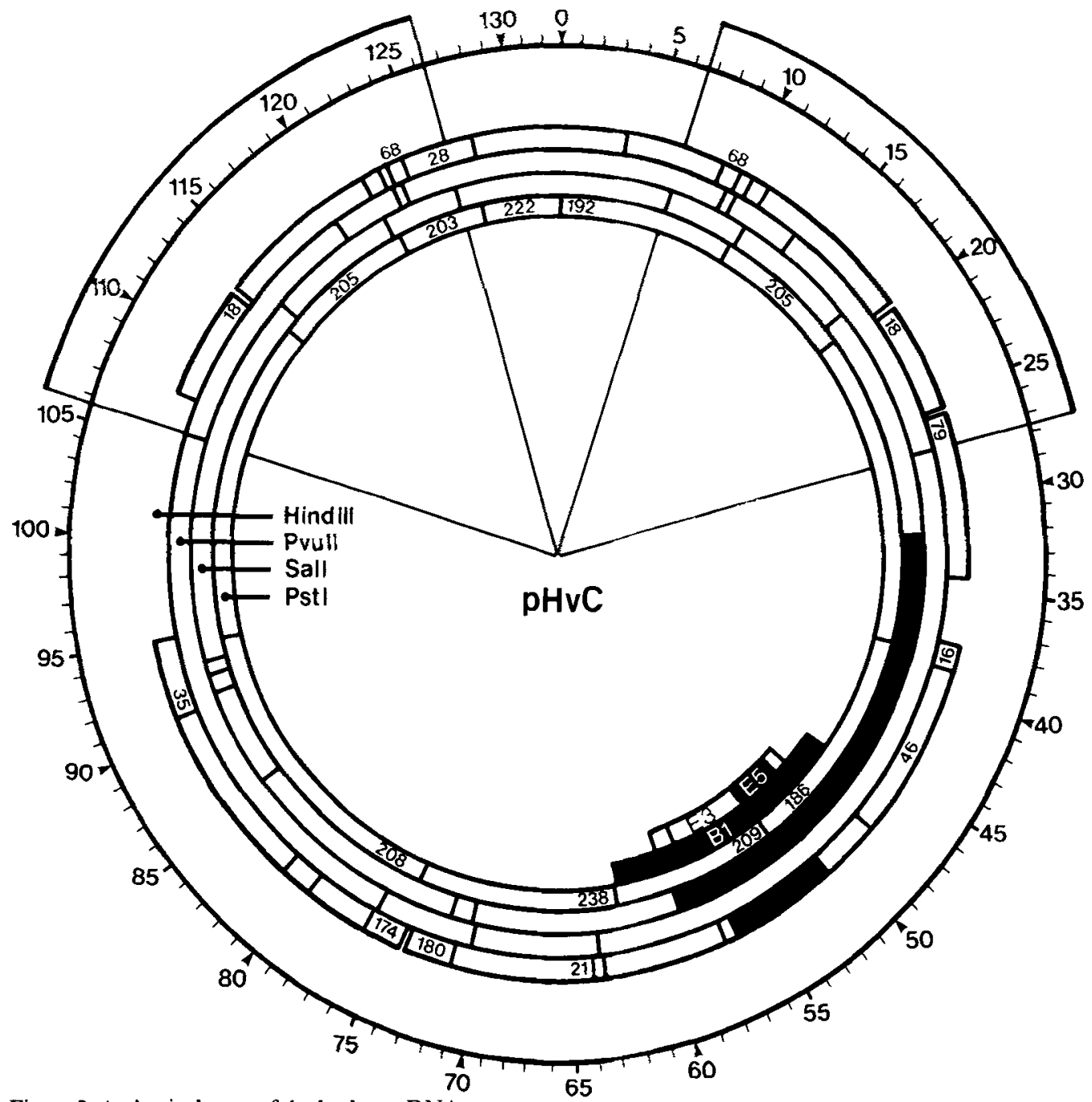

Figure 2. A physical map of the barley cpDNA.

Restriction fragment sizes can be read on the circular scale. Well characterized fragments found in recombinant plasmids are designated with their $\mathrm{pHvC}$ numbers. The black shaded fragments hybridize with the maize rbcL probes. 
was cut with the restriction endonucleases PstI, SalI and PvuII, and the sites mapped with the aid of double and triple digestions. The subfragments thus obtained from the cloned PstI fragments are identified in Table I, where they are listed according to size. With the exception of the regions covered by the $20.7 \mathrm{kbp}$ and $18.4 \mathrm{kbp}$ PstI fragments (which have not been cloned) this permits the construction of the PstI/SalI/PvuII map presented in Figure 1. Cross-checking was done against restriction fragment patterns produced from intact chloroplast DNA with the three endonucleases (Figure 3). The restriction sites in the $20.7 \mathrm{kbp}$ and $18.4 \mathrm{kbp}$ Pstl fragments were mapped with the aid of this figure.

Like maize and wheat the barley cpDNA has

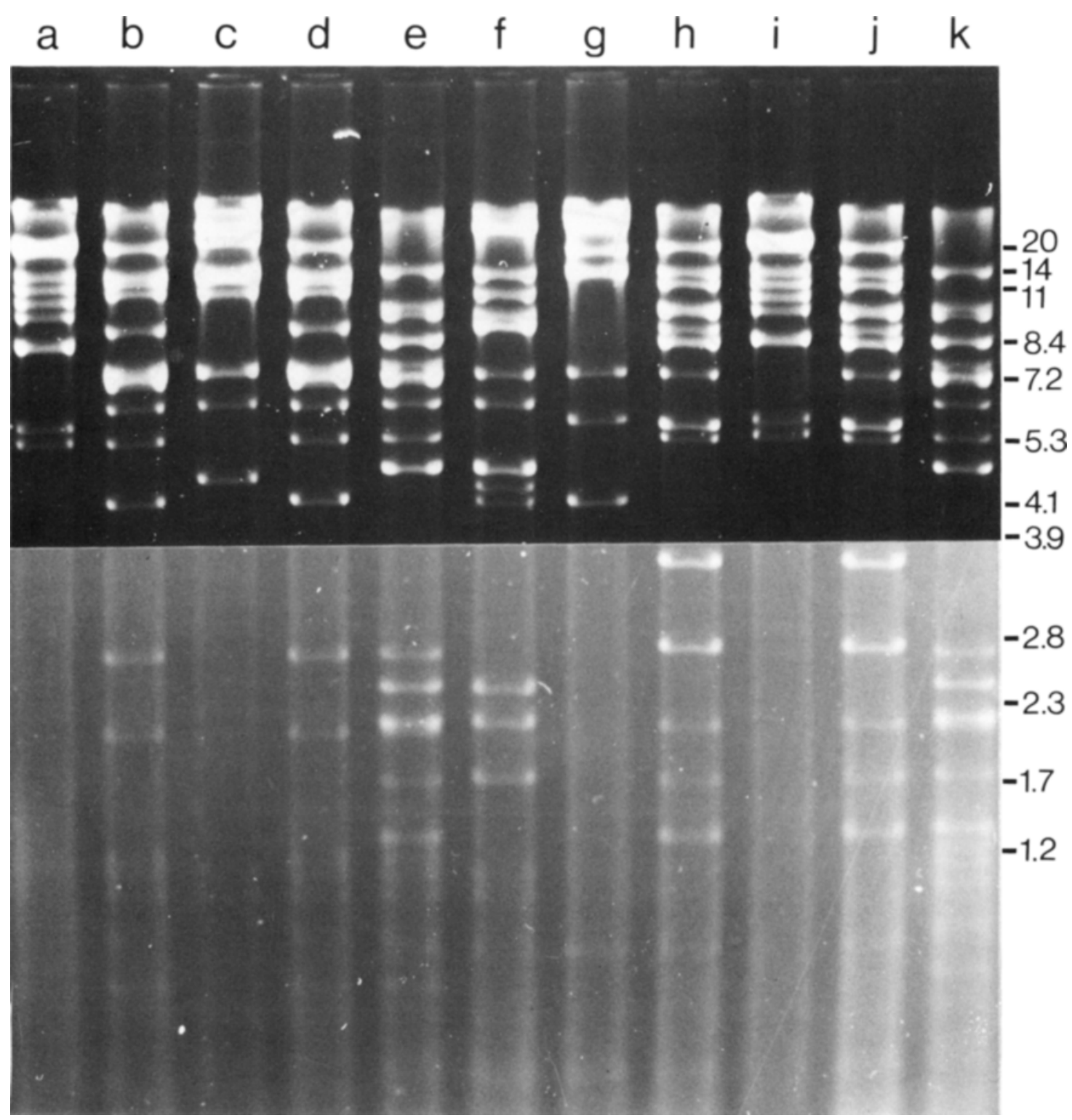

Figure 3. Restriction endonuclease digestions of barley chloroplast DNA.

Approximate sizes of restriction fragments $(\mathrm{kbp})$ can be obtained by the scale to the right. Digestions were performed with a) and i) PstI; c) SalI; g) PvuII; b) and d) PstI + SalI; f) SalI + PvuII; h) and j) PstI + PvuII; e) and k) PstI + Sall + PvuII. 
an inverted repeat, a small and a large single copy region. Summation of fragment sizes give approximately 134,000 bp for the barley cpDNA, $137,000 \mathrm{bp}$ for the maize cpDNA and 135,000 bp for the wheat cpDNA. Whether these differences are significant cannot be determined at present.

When the PvuIl-maps for the barley and maize cpDNAs are compared the following differences are found: In maize, the small single copy region is covered by two Pvull fragments of $15.3 \mathrm{kbp}$ and $3.1 \mathrm{kbp}$. In barley, the small single copy region is covered by a single $18.4 \mathrm{kbp}$ fragment. Inside the inverted repeat, the maize fragments of $4.15 \mathrm{kbp}$ and $15.3 \mathrm{kbp}$ are homologous to the $4.1 \mathrm{kbp}$ and $14.0 \mathrm{kbp}$ fragments, while site

Table I.

List of restriction endonuclease fragments obtained from the barley chloroplast DNA arranged according to approximate size in $\mathbf{k b p}$.

\begin{tabular}{|c|c|c|c|c|c|c|c|c|c|c|}
\hline PstI & $\mathrm{pHvC}$ & Sall & PvulI & $\begin{array}{l}\text { PstI } \\
\text { SalI } \\
\end{array}$ & $\mathrm{pHvC}$ & $\begin{array}{c}\text { PstI } \\
\text { PvuII } \\
\end{array}$ & $\mathrm{pHvC}$ & $\begin{array}{c}\text { SalI } \\
\text { PvulI }\end{array}$ & $\begin{array}{c}\text { PstI } \\
\text { SalI } \\
\text { PvuII } \\
\end{array}$ & $\mathrm{pHvC}$ \\
\hline 20.7 & - & 28.1 & 36.9 & 18.4 & - & 18.6 & 208 & 28.1 & 13.5 & 186 \\
\hline 20.4 & 208 & 20.3 & 28.6 & 13.5 & 186 & 13.5 & 186 & 13.8 & 10.0 & 208 \\
\hline 18.4 & - & 14.2 & 18.4 & 12.7 & - & 11.7 & - & 10.9 & 10.0 & - \\
\hline 13.5 & 186 & 13.9 & 14.0 & 11.9 & 208 & 10.0 & - & 10.0 & 8.4 & - \\
\hline 12.7 & 238 & 13.8 & 14.0 & 9.3 & 238 & 10.0 & 209 & 9.4 & 8.4 & - \\
\hline 10.9 & 192 & 11.8 & 7.2 & 7.5 & 209 & 9.2 & 192 & 9.4 & 7.5 & 209 \\
\hline 10.0 & 209 & 7.2 & 5.7 & 7.2 & 205 & 8.4 & - & 7.2 & 7.2 & 205 \\
\hline 8.4 & 205 & 7.2 & 4.1 & 7.2 & 205 & 8.4 & - & 6.0 & 7.2 & 205 \\
\hline 8.4 & 205 & 6.0 & 4.1 & 7.2 & - & 7.2 & 238 & 4.6 & 6.7 & 192 \\
\hline 5.6 & 203 & 4.5 & 0.3 & 6.7 & 192 & 5.6 & 205 & 4.6 & 6.0 & 208 \\
\hline \multirow[t]{26}{*}{5.3} & 222 & 4.5 & 0.3 & 6.0 & 208 & 5.6 & 205 & 4.5 & 5.3 & 222 \\
\hline & & 1.2 & & 5.3 & 222 & 5.3 & 222 & 4.3 & 4.6 & 205 \\
\hline & & 1.1 & & 4.2 & 192 & 3.7 & 203 & 4.1 & 4.6 & 205 \\
\hline & & 0.8 & & 4.2 & 203 & 3.7 & 238 & 2.5 & 4.5 & - \\
\hline & & & & 2.6 & 209 & 2.8 & 205 & 2.5 & 2.6 & 209 \\
\hline & & & & 2.1 & 238 & 2.8 & 205 & 2.2 & 2.5 & 205 \\
\hline & & & & 1.4 & 203 & 2.0 & 208 & 2.2 & 2.5 & 205 \\
\hline & & & & 1.2 & 238 & 1.7 & 238 & 1.7 & 2.2 & 203 \\
\hline & & & & 1.1 & 208 & 1.4 & 203 & 1.7 & 2.2 & 192 \\
\hline & & & & 1.0 & 205 & 1.4 & 192 & 1.2 & 2.1 & 238 \\
\hline & & & & 1.0 & 205 & 0.3 & 203 & 1.1 & 2.0 & 208 \\
\hline & & & & 0.9 & 208 & 0.3 & 192 & 0.8 & 1.7 & 238 \\
\hline & & & & 0.8 & 208 & & & 0.3 & 1.4 & 203 \\
\hline & & & & 0.3 & 205 & & & 0.3 & 1.4 & 192 \\
\hline & & & & 0.3 & 205 & & & 0.2 & 1.4 & 203 \\
\hline & & & & & & & & & 1.2 & 238 \\
\hline & & & & & & & & & 1.1 & 208 \\
\hline & & & & & & & & & 1.1 & 205 \\
\hline & & & & & & & & & 1.0 & 205 \\
\hline & & & & & & & & & 0.9 & 208 \\
\hline & & & & & & & & & 0.8 & 208 \\
\hline & & & & & & & & & 0.3 & 192 \\
\hline & & & & & & & & & 0.3 & 203 \\
\hline & & & & & & & & & 0.3 & 205 \\
\hline & & & & & & & & & 0.3 & 205 \\
\hline & & & & & & & & & 0.2 & 238 \\
\hline 134.3 & & 134.4 & 133.6 & 133.9 & & 133.4 & & 133.8 & 133.3 & \\
\hline
\end{tabular}


differences appear in the domain towards the single copy region.

Three PvulI fragments of $21.2 \mathrm{kbp}, 7.3 \mathrm{kbp}$ and $6.6 \mathrm{kbp}$ in the large single copy region of maize cpDNA are fused into one very large fragment in the barley cpDNA. Also in maize, a 13 $\mathrm{kbp}$ PvuIl fragment is split into two fragments in barley (7.2 and $5.7 \mathrm{kbp})$.

The region of the $20.4 \mathrm{kbp}$ PstI fragment in barley is quite different in maize with respect to SalI sites. Five fragments are present in barley but only three are found in maize and six in wheat. A high degree of polymorphism is found among the three species in this part of the chloroplast genome.

On the whole, wheat and barley cpDNA organisations are more similar to one another than to the maize cpDNA. This is not surprising, since wheat and barley are both eurasian species and are taxonomically closely placed in the same subfamily (Hordeae) whereas maize in the subfamily Maydeae originated on the American continent.

\subsection{Localization of the rbcL gene on the barley chloroplast genome}

Figure 1 also shows the approximate position of the gene for the large subunit of ribulose bisphosphate carboxylase (rbcL) of maize (24, 35 ) and wheat (9) cpDNAs. The two genes are in equivalent positions in the two genomes. In order to map the rbcL gene on the barley genome, heterologous hybridization was performed between radioactive probes prepared from the

Figure 4. Localization of the gene for the large subunit of ribulose bisphosphate carboxylase on the barley cpDNA.

First, third and fifth lanes show the fragment pattern of cpDNA digested with EcoRI, BamHI and HindIII, respectively, after electrophoresis on an $0.8 \%$ agarose gel. The gel was Southern blotted and hybridized with a 567 bp PstI fragment from the maize cpDNA recombinant plasmid containing part of the maize rbcL gene. Autoradiographs of the hybridized and washed filters are shown in the second, fourth and sixth lane. The scale on the right shows fragment sizes in kbp. The ethidium bromide stained gel shows a background of nuclear and mitochondrial DNA which does not interfere in this experiment. maize LS clone pZmC3711 and filterbound restriction endonuclease fragments of the barley cpDNA. When nick translated pZmC3711 was hybridized to Sall, BamHI , EcoRI and HindIII fragments of barley cpDNA, the following pat-

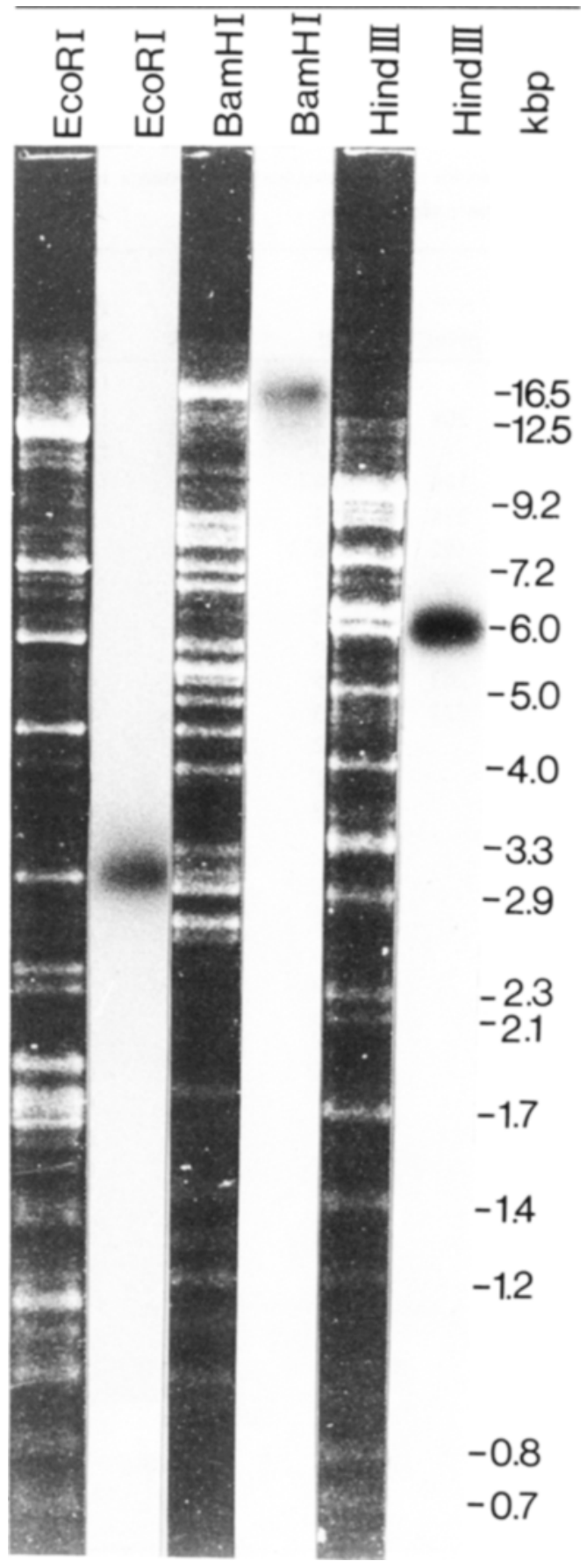


tern was observed: Only the largest BamHI and Sall fragments, of $16.5 \mathrm{kbp}$ and $28 \mathrm{kbp}$, respectively, were binding radioactive $\mathrm{pZmC} 3711$. The hybridization to the $28 \mathrm{kbp}$ Sall fragment reveals that the barley rbcL gene is located in the same region of the genome as in maize and wheat (cf. Figure 1). When hybridized to EcoRI fragments, radioactivity was about equally shared between two fragments of about 5.7 and $3.1 \mathrm{kbp}$. Of the HindIII fragments two hybridized with this probe, the fragment of $6.0 \mathrm{kbp}$ giving a ten-fold stronger response than that with a size of $3.3 \mathrm{kbp}$.

Table II.

List of the HindIII endonuclease fragments of barley chloroplast DNA.

IR = fragments found within the inverted repeat. n.d. not determined.

\begin{tabular}{|c|c|c|c|}
\hline $\begin{array}{l}\text { HindIII } \\
\text { fragment }\end{array}$ & $\begin{array}{l}\text { Size } \\
\text { kbp }\end{array}$ & Coordinates & $\mathrm{pHvC}$ \\
\hline 1 & 9.5 & $80.4-90.0$ & 208 \\
\hline 2a IR & 9.2 & $10.3-19.5$ & 205 \\
\hline $2 \mathrm{~b} \mathrm{IR}$ & 9.2 & $113.0-122.2$ & 205 \\
\hline 3 & 8.8 & $127.5-0-3.4$ & $222+192$ \\
\hline 4 & 8.4 & $25.3-33.7$ & 73 \\
\hline 5 & 8.3 & $39.0-47.5$ & $46+186$ \\
\hline 6 & 7.4 & $64.0-71.4$ & $21+238$ \\
\hline $7 \mathrm{a} \mathrm{rbcL}$ & 6.0 & $50.8-56.8$ & $209+186$ \\
\hline $7 b$ & 6.0 & $57.4-63.4$ & $209+238$ \\
\hline $7 \mathrm{c}$ & 6.0 & n.d. & \\
\hline $8 \mathrm{a}$ IR & 5.8 & $19.5-25.3$ & 18 \\
\hline $8 \mathrm{~b} \mathrm{IR}$ & 5.8 & $107.2-113.0$ & 18 \\
\hline 9 & 5.0 & $3.4-\quad 8.4$ & 192 \\
\hline 10 & 4.0 & $90.0-94.0$ & 35 \\
\hline $1 \mathrm{la}$ & 3.3 & $47.5-50.8$ & 186 \\
\hline $11 b$ & 3.3 & $75.4-78.7$ & 208 \\
\hline $11 \mathrm{c}$ & 3.3 & $124.2-127.5$ & 28 \\
\hline 12 & 2.9 & n.d. & \\
\hline 13 & 2.3 & $71.4-73.7$ & $180+238$ \\
\hline 14 & 2.1 & n.d. & 115 \\
\hline $15 \mathrm{a}$ & 1.7 & $73.7-75.4$ & $174+208$ \\
\hline $15 b$ & 1.7 & $78.7-80.4$ & 208 \\
\hline 16 & 1.4 & $37.6-39.0$ & $16+186$ \\
\hline 17 & 1.2 & n.d. & 147 \\
\hline 18a IR & $0.8)$ & & \\
\hline 19a IR & $0.7)$ & $8.4-10.3$ & $192+205+68$ \\
\hline 20a IR & $0.5)$ & & \\
\hline $18 \mathrm{~b}$ IR & $0.8)$ & & \\
\hline 19b IR & $0.7)$ & $122.2-124.2$ & $203+205+68$ \\
\hline $20 \mathrm{~b}$ IR & $0.5)$ & & \\
\hline Total & 126.2 & 114.0 & \\
\hline
\end{tabular}

The data obtained with a more specific rbcL probe are given in Figure 4 as this permitted a positioning of the barley rbcL gene. Here, the $567 \mathrm{bp}$ Pstl fragment from pZmC3711 (cf. 2.9) hybridizes only with the $3.1 \mathrm{kbp}$ EcoRI fragment and with the $6.0 \mathrm{kbp}$ HindIII fragment.

The results of the EcoRI, BamHI and HindIII restriction endonuclease analyses of the recombinant plasmids pHvC209 and 186 are included in the map shown in Figure 2 (cf. section 3.3.). It was possible to locate the BamHI sites and the EcoRI sites in the $6.0 \mathrm{kbp}$ HindIII fragment and in the neighboring regions of the barley genome. The fragments shaded black in Figure 2 are those hybridizing to the maize rbcL probe, e.g. the E5 $(3.1 \mathrm{kbp})$ and the B1 $(16.5 \mathrm{kbp})$ fragments are shown. The position of the EcoRI site separating the E3 (5.7 kbp) and E5 (3.1 kbp) fragments suggests a direction of transcription which is the same as that of the maize and wheat rbcL genes. This EcoRI site is about $200 \mathrm{bp}$ inside the insert of the recombinant plasmid pHvC209, containing the $10 \mathrm{kbp}$ Pstl fragment. In the maize rbcL sequence there is a PstI site $167 \mathrm{bp}$ downstream from the ATG start codon and there is an EcoRI site 33 bp upstream from this triplet. The hybridizations suggest that these two sites are equivalent to the sites now found in the barley cpDNA and thus that they are transversed by the 5 '-end of the LS mRNA. The $567 \mathrm{bp}$ maize rbcL probe starts at the mentioned PstI site and proceeds downstream to nucleotide pair 734 , that is in the opposite direction relative to the EcoRI site. This interpretation is in agreement with the wheat data for this region of the cpDNA $(22,24)$. The wheat rbcL gene has been associated with an EcoRI fragment of $2.8 \mathrm{kbp}$. This fragment is shorter than the barley E5 fragment probably due to the position of another EcoRI site about $100 \mathrm{bp}$ downstream from the PstI site (22). Such a site has eluded identification in the barley cpDNA. To this should be added, that the second PstI site creating the $567 \mathrm{bp}$ rbcL probe from maize is absent in wheat as well as in barley cpDNA. Concerning the genes atpB and atpE encoding a $2.2 \mathrm{~kb}$ transcript partly contained in pZmC3711 (27) and the corresponding $2.4 \mathrm{~kb}$ transcript encoded by pTac39 of wheat (22), it appears that the equivalent sequences in the barley cpDNA are contained in E3 (5.7 kbp). 


\subsection{Recombinant plasmids and the location of HindIII sites}

When the barley cpDNA is digested with HindIII and the fragments are separated by gel electrophoresis, 15 groups of fragments are separated in the molecular size region between 700 and 10,000 bp (Figure 4). As can be seen in Figure 4 , seven groups contain two or more fragments. Scanning of silver grain intensity on enlarged negatives and normalization to fragment size, yields a HindIII fragment collection of 28 fragments for this region (Table II). These add up to $126.2 \mathrm{kbp}$, while the rest of the genome has to be accounted for by small fragments below 700 bp. Thus, HindIII appears to restrict the barley cpDNA into at least 40 fragments.

The restriction endonuclease analyses of the many recombinant plasmids containing either PstI or HindIII fragments, permits the addition of a partial map of HindIII sites in the chloroplast DNA (Figure 2). The map discloses the coordinates for 26 of the 30 fragments listed in Table II. The coordinate 0 corresponds to the PstI site in the middle of the small single copy region. Two small $300 \mathrm{bp}$ fragments, 20a and $20 \mathrm{~b}$, were found during analysis of $\mathrm{pHvCl} 92$ and $\mathrm{pHvC203}$. They were added to the list beside the 28 distinguishable fragments mentioned above. Likewise, two other small fragments accounting for $1.2 \mathrm{kbp}$ were found in $\mathrm{pHvC} 238$ and in pHvC209 (cf. Figure 2). Hereby $127.4 \mathrm{kbp}$ of the barley cpDNA are accounted for as HindIII fragments. Of these, four fragments of 6.0, 2.9, 2.1 and $1.4 \mathrm{kbp}$ have not yet been localized in the map. They are assumed to occupy the major part of the open HindIII sections, with coordinates 33.7-37.6 and coordinates 94.0107.2 , i.e. $12.2 \mathrm{kbp}$ out of $18.1 \mathrm{kbp}$. Thus about $6 \mathrm{kbp}$ are left for the group of small HindIII fragments.

There are still unclear points in the HindIII map. For instance, it is not yet clear whether the fragment represented by $\mathrm{pHvC1}$ is immediately neighboring the $9.2 \mathrm{kbp}$ fragment of the inverted repeat, or whether the fragment represented by $\mathrm{pHvC79}$ is neighboring the $\mathrm{pHvC1}$ fragment on the right side of the circle. It cannot be excluded either, that very small HindIII fragments have escaped detection in the analyses of the PstI plasmids.

\subsection{The RNA isolated from developing plastids}

Figure 5 shows the picture obtained after ethidium bromide staining of a gel with plastid

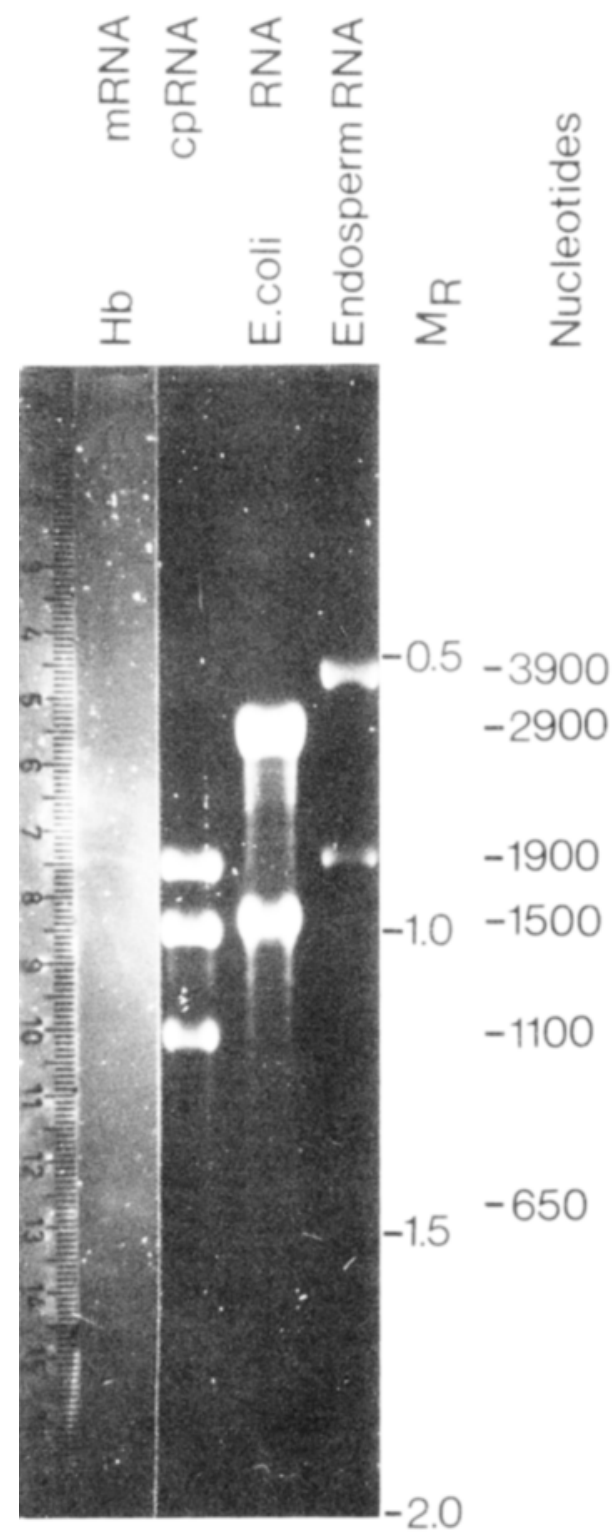

Figure 5. Agarose gel electrophoresis of RNA denatured with formaldehyde.

HbmRNA: $3 \mu$ l globin mRNA (650 nucleotides), cpRNA: $6 \mu \mathrm{g}$ of total RNA isolated from developing plastids, E. coli RNA: $10 \mu \mathrm{g}$ of total RNA isolated from Escherichia coli, endosperm RNA: $3 \mu \mathrm{g}$ of total RNA from developing barley endosperms. $M_{R}$ : Mobility relative to $E$. coli $16 \mathrm{~S}$ rRNA. The number of ribonucleotides in the visible RNA species are shown in the scale to the right. 
RNAs separated in a denaturing system together with a set of marker RNAs. Three predominant species of RNA are present in the cpRNA sample. These are the $16 \mathrm{~S}$ rRNA (1500 nucleotides) and the two fragments of the 23S rRNA (1900 and 1000-1100 nucleotides). The formaldehyde system used here, as well as urea-polyacrylamide and glyoxal-agarose gel systems, failed to reveal visible amounts of $5 \mathrm{~S}$ rRNA and the 4S tRNAs. Accordingly, they are lost in the procedure, probably during the pelleting through the $\mathrm{CsCl}$ cushions. On the other hand, a very faint band is visible in the region corresponding to the $25 \mathrm{~S}$ rRNA (3900 nucleotides) of the barley cytoplasmic ribosomes (endosperm RNA), suggesting that the cpRNA preparations are slightly contaminated with cytoplasmic RNA.

The integrity of the three rRNA bands indicates, that the RNA prepared by the guanidinium thiocyanate procedure is of adequate quality for the intended DNA/RNA-paper hybridizations. Examples of such hybridizations are shown in Figure 6. Lane a shows a hybridization experiment with nick translated purified pBR322, indicating that $\mathrm{pBR}$ sequences contaminating the cpDNA fragments used as probes (cf.section 2.10.), will not significantly contribute to the hybridization responses. Lane $\mathbf{b}$ shows another control hybridization in which a recombinant plasmid, with an insert of $9.0 \mathrm{kbp}$, was used as a probe. Restriction endonuclease mapping of this plasmid excluded that the insert originates from cpDNA. Thus the two faint RNA bands of about $2.5 \mathrm{~kb}$, which appeared after six days of autoradiography, could be either large cytoplasmic mRNAs from membrane bound polyribosomes, hnRNAs from nuclei or even mitochondrial RNAs. Lanes $\mathbf{c}$ and $\mathbf{d}$ show the hybridizations of filterbound RNA with nick translated recombinant plasmids containing inserts of $2.1 \mathrm{kbp}$ (pHvCl15) and $1.2 \mathrm{kbp}$ (pHvC147) (Table II). After autoradiography for 24 hours lane $c$ reveals that the $2.1 \mathrm{kbp}$ fragment hybridizes with a major band of $4.0 \mathrm{~kb}$ and three minor bands between 2.5 and $3.5 \mathrm{~kb}$. The single transcript of $1.3 \mathrm{~kb}$ found to hybridize with pHvC147 (lane d) must be an abundant chloroplast transcript, since the shown intensity appeared after only 8 hours of autoradiography.

It is indicated by these experiments that auto-

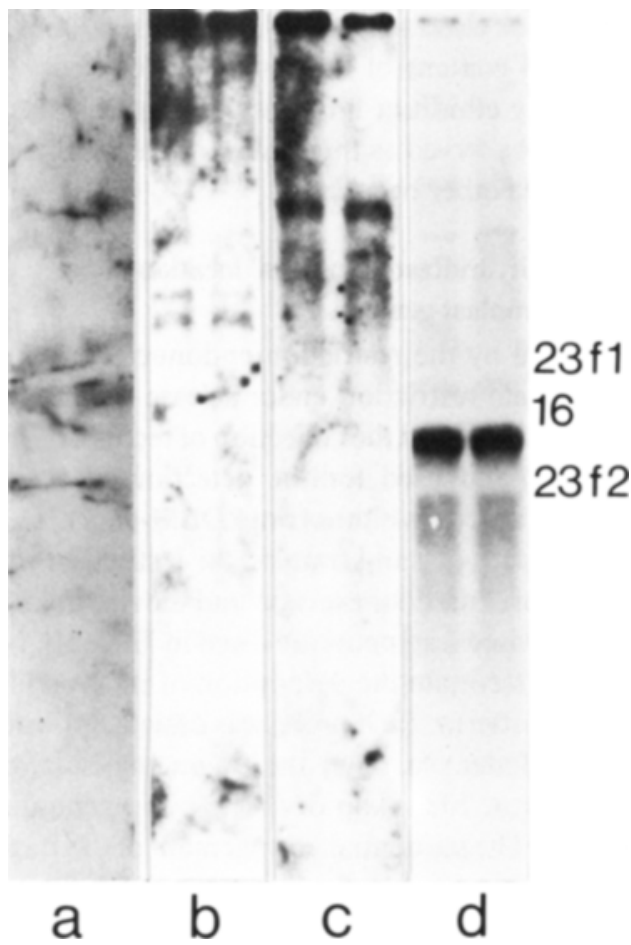

Figure 6. Autoradiographs of radioactive DNAcpRNA hybrids.

Two samples of cpRNA were separated on formaldehyde-agarose gels, blotted onto DBM-paper and subsequently hybridized with nick translated DNA: lane a, $0.2 \mu \mathrm{g}$ of $\mathrm{pBR} 322$, lane $\mathrm{b}, 0.2 \mu \mathrm{g}$ of a non-

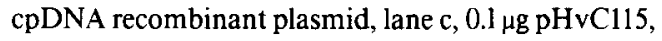
lane $\mathrm{d}, 0.1 \mu \mathrm{g}$ of $\mathrm{pHvCl}$. The designations $16,23 \mathrm{fl}$ and $23 \mathrm{f} 2$ indicate the positions of chloroplast $16 \mathrm{~S}$ rRNA and the two fragments $f 1$ and $f 2$ of the chloroplast 23S rRNA. Hybridization to DNA contaminating the cpRNA is seen at the top of the hybridization strips.

radiography for less than 24 hours is unlikely to reveal hybridization between DNA sequences contaminating the plasmid inserts and the RNA from the plastids. They also fail to reveal hybridization between plasmid inserts and RNA not of plastid origin. Therefore in the subsequent experiments autoradiography was limited to 24 hours or less.

Yield of RNA preparations from $100 \mathrm{~g}$ seedling leaves greened for various length of time (cf. section 2.2) varied possibly due to changes of plastid stability during development. The RNA preparations were dissolved in $\mathrm{H}_{2} \mathrm{O}$ at con- 
centrations close to $3 \mathrm{mg} / \mathrm{ml}$, and these adjusted for equal content of the three rRNA bands as judged by ethidium bromide staining. Thereby the rRNAs served as internal standards for content of the other transcripts.

\subsection{The hybridization probes' location in the chloroplast genome}

Guided by the restriction endonuclease map appropriate restriction endonuclease fragments were isolated from the collection of recombinant plasmids and used for the detection of chloroplast transcripts blotted onto DBM-paper. The recombinant plasmid sources, the restriction endonucleases used for excision and the size in $\mathrm{kbp}$ of the excised fragments are listed in Table III. In order to facilitate the description of the hybridization patterns, each probe was designated with a small letter. As seen, the fragments isolated cover about $108.4 \mathrm{kbp}$ of the $134 \mathrm{kbp}$ genome, i.e. $81 \%$. The sequential arrangement of the fragments in the genome is outlined in Figure 7.

The isolation of the fragments to be used as probes was performed in order to avoid 1) cross contamination between fragments isolated from the same plasmids, and 2) to provide a decent coverage of the genome. The former was approached by chosing restriction fragments differing significantly in size (e.g. b, $\mathbf{c}, \mathbf{d}$ or $\mathbf{p}, \mathbf{q}$ ) and checking the purity of the preparations. With one exception, re-electrophoresis of $0.5 \mu \mathrm{g}$ aliquots of the isolated fragments failed to reveal any detectable cross-contamination as judged by long exposure photography of the ethidium bromide stained DNA. HindIII/PstI fragment $\mathbf{h}$ from $\mathrm{pHvC209}$, was contaminated with about $5 \%$ i-fragment, whereas no contamination was seen in the i preparation.

Some probes were prepared from different restriction endonuclease digestions, or probes covering the same sequences of the cpDNA were isolated from alternative recombinant plasmids (e.g. al and a2, cf. Table III). In the case of pHvC35 the insert cannot be separated from the vector DNA.

\subsection{Transcripts hybridizing with chloroplast DNA fragments}

On the assumption that chloroplast genomes from higher plants have a $\mathrm{G}+\mathrm{C}$ content of close
Table III.

Probes used for characterization of chloroplast transcripts. The probes designated with the number 2 contain sequences also present in those numbered 1 . $\$$ Insert of pHvC35 was not isolated.

\begin{tabular}{|c|c|c|c|c|c|}
\hline Probe & $\begin{array}{l}\text { Plasmid } \\
\text { Source }\end{array}$ & HindIII & PstI & PvuII & Size kbp + \\
\hline a1 & $\mathrm{pHvC} 35 \S$ & $x$ & & & 4.0 \\
\hline a2 & $\mathrm{pHvC} 208$ & $\mathrm{X}$ & $\mathrm{X}$ & & (3.5) \\
\hline b & $\mathrm{pHvC2} 28$ & $X$ & & & 9.5 \\
\hline c & $\mathrm{pHvC208}$ & $x$ & & & 1.7 \\
\hline d & $\mathrm{pHvC} 208$ & $X$ & & & 3.3 \\
\hline el & $\mathrm{pHvC174}$ & $x$ & & & 1.7 \\
\hline e2 & $\mathrm{pHvC208}$ & & $\mathrm{X}$ & $\mathrm{X}$ & $(1.6)$ \\
\hline f1 & $\mathrm{pHvC1} 80$ & $X$ & & & 2.3 \\
\hline f 2 & pHvC238 & $\mathrm{X}$ & & & (2.3) \\
\hline g1 & $\mathrm{pHvC} 238$ & $\mathrm{X}$ & & & 7.4 \\
\hline g2 & $\mathrm{pHvC} 21$ & X & & & (7.4) \\
\hline h & pHvC209 & $x$ & $\mathrm{X}$ & & 4.6 \\
\hline i & pHvC209 & $\mathrm{X}$ & $\mathrm{X}$ & & 4.9 \\
\hline $\mathbf{j}$ & $\mathrm{pHvC} 186$ & $X$ & & & 3.3 \\
\hline k1 & $\mathrm{pHvC186}$ & $\mathrm{X}$ & & & 8.3 \\
\hline k2 & pHvC46 & $\mathrm{X}$ & & & (8.3) \\
\hline I & $\mathrm{pHvC16}$ & $\mathrm{X}$ & & & 1.4 \\
\hline m & $\mathrm{pHvC79}$ & $X$ & & & 8.4 \\
\hline n & $\mathrm{pHvC} 18$ & $\mathrm{X}$ & & & 5.8 \\
\hline $\mathbf{0}$ & $\mathrm{pHvC205}$ & & $\mathrm{X}$ & & 8.4 \\
\hline $\mathbf{p}$ & $\mathrm{pHvC192}$ & $\mathrm{X}$ & & & 5.0 \\
\hline$q$ & $\mathrm{pHvC1} 192$ & $X$ & $X$ & & 3.4 \\
\hline $\mathbf{r}$ & $\mathrm{pHvC} 222$ & & $X$ & & 5.3 \\
\hline $\mathbf{s}$ & $\mathrm{pHvC203}$ & & $X$ & & 5.6 \\
\hline$t$ & $\mathrm{pHvC} 205$ & & $\mathrm{X}$ & & 8.4 \\
\hline \multirow[t]{2}{*}{$\mathbf{u}$} & $\mathrm{pHvC18}$ & $\mathrm{X}$ & & & 5.8 \\
\hline & & & & & 108.4 \\
\hline
\end{tabular}

to $38 \%(6)$, and that this also applies to the individual fragments isolated from barley cpDNA the hybridizations were performed at approximately $\mathrm{T}_{\mathrm{m}}-21{ }^{\circ} \mathrm{C}$. The subsequent stringent washings of the filters were performed in 0.015 $\mathrm{M}-\mathrm{NaCl}, 1.5 \mathrm{~mm}-\mathrm{Na}$-citrate, $0.2 \%(\mathrm{w} / \mathrm{v}) \mathrm{Na}-$ dodecyl sulphate at $55^{\circ} \mathrm{C}$, corresponding to $\mathrm{T}_{\mathrm{m}}$ $12{ }^{\circ} \mathrm{C}$. Results of the hybridizations performed with radioactive probes, made from the fragments described in section 3.5. are shown in Figure 7. For each fragment probe filters containing two electrophoretically separated RNA-samples, one from etioplasts and one from eight hour greened plastids, were employed. As depicted in 


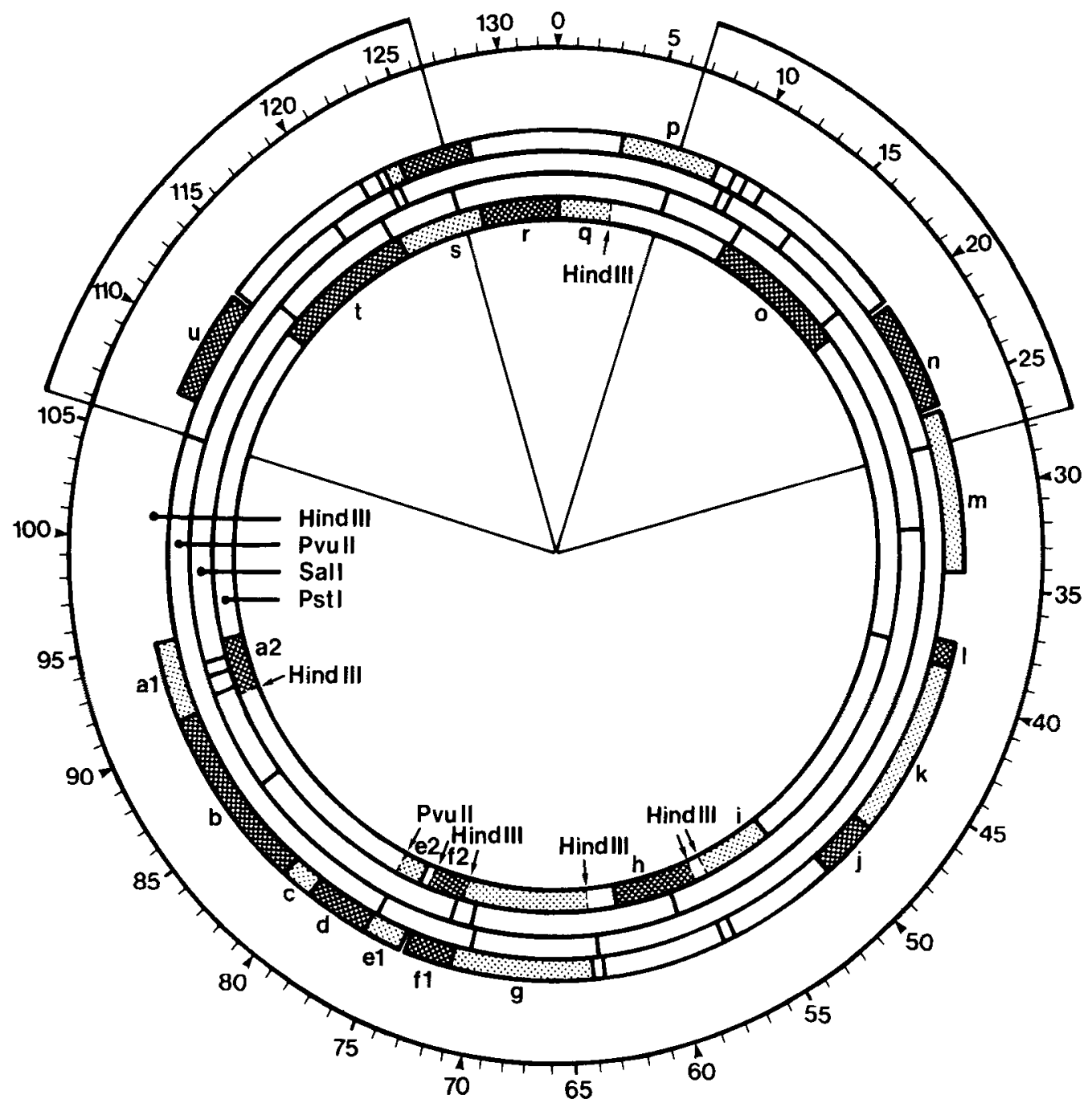

Figure 7. The position of the restriction endonuclease fragments a to $\mathbf{u}$ isolated in order to identify transcripts of the chloroplast genome.

Figure 8, the data suggest that hybridization conditions may have been too stringent in some cases (b, c, d) and maybe not overly stringent in others (a, e, $\mathbf{f}, \mathbf{k}$ etc.). This might be indicative of low and high $G+C$ contents, respectively. Since coding sequences (protein-encoding) are normally more $\mathrm{G}+\mathrm{C}$ rich than non-coding sequences, there does seem to be some correlation between hybridization conditions and the hybridization responses with the different probes: The diversity of the responses indicate that certain regions of the genome are more heavily transcribed than others, or that high contents of $\mathrm{G}+\mathrm{C}$ and possibly partial sequence homology be- tween certain transcripts may give rise to false hybridization responses. Assuming the former possibility and keeping the second in mind, I will present a systematic description of the data given in Figure 8 and interpreted in Figure 10.

\subsubsection{Large single copy region}

The first hybridization strip (a2) shows that the $3.5 \mathrm{kbp}$ HindIII/Pstl fragment hybridizes to at least five major transcripts. Two of these are larger than $3.9 \mathrm{~kb}$ and are larger than the fragment itself. They must therefore extend into neighboring fragments. The third transcript is about $2.9 \mathrm{~kb}$ and is the second strongest 
hybridizing band. The strongest hybridizing band is found at $0.86 \mathrm{~kb}$. For this transcript stronger hybridization is observed for RNA from eight hour greened plastids than with etioplast RNA. This suggests either that the RNA is synthesized preferentially in the light or that there are two species of RNA of this size, one which is synthesized in the dark and in the light and one which is only synthezised in the light. A fifth band is found at $0.60 \mathrm{~kb}$. For comparison Figure 9 shows the hybridization of the slightly larger probe al with the RNA preparations from eight different plastid developmental stages. This 4.0 kbp HindIll fragment shows hybridization to at least two additional bands. The two additional bands correspond to a transcript of $1.8 \mathrm{~kb}$ and one of only 350 nucleotides, which seems most intense during the early to middle stages of greening. Figure 10 also shows that the $0.86 \mathrm{~kb}$ band hybridizes with increasing intensity as greening proceeds. There seems to be a slightly enhanced synthesis of the $0.60 \mathrm{~kb}$ transcript during greening. Parts of the a-region of the chloroplast genome thus are subject to light regulated transcription. Two additional points can be made here. Firstly, the similarity of the al- and a2-hybridization responses, suggest that there are no major contributions to 2 by contaminants of other probes isolated from the same large plasmid ( $\mathrm{pHvC208)}$. Secondly, the a probes contain many $\mathrm{G}+\mathrm{C}$ rich restriction endonuclease sites. To what extent the relatively large number of hybridizing bands are due to incomplete denaturation cannot be decided, but it can be pointed out that the experimental procedures followed here have not deviated significantly from those described elsewhere $(28,31)$.

The same transcript complexity is not found in the b-, $\mathbf{c}$ - and d-region. It appears that the coding for two a-transcripts extend into the DNA sequence of the $\mathbf{b}$-region, one is the largest and the other is a $0.86 \mathrm{~kb}$ transcript. These observations support the notion that the transcription complexity from the a-fragment is real. A third presumably overlapping transcript of $2.95 \mathrm{~kb}$ is found for the $\mathbf{b}$ - and the c-regions. It seems more strongly synthesized in greening seedlings than in dark grown seedlings. No major transcripts hybridize with the d-probe. Repeated hybridization and washing at lower stringency did not re- veal any new RNA species, suggesting that this region is quite inactive in transcription.

The e-, $f$ - and g-probes also illustrate a region complex in transcription. Here the hybridizations gave highly reproducible patterns, when the different $e-, f$ - and $g$-fragments were used as probes (cf. Table III). Several transcripts hybridize to two or all three fragments, but with different intensities. Thus the $1.6 \mathrm{~kb}$ e2-probe hybridizes strongly with two to three transcripts, one of $3.2 \mathrm{~kb}$ and one or two of $2.6 \mathrm{~kb}$. There are hints of these transcripts in the $\mathbf{n}$-hybridization pattern. The f-probes show a strong transcript band of $3.5 \mathrm{~kb}$, which seems to extend into the efragments and also with low intensity into the $\mathrm{g}$ fragment. Breakdown products of this transcript blur the slightly faster migrating transcripts described above for the e-region. The Pstl site separating $e$ and $f$ has been identified in wheat to be inside the atpH gene (21).

Figure 8 lane g, and Figure 9 both identify a very large (above $4 \mathrm{~kb}$ ) transcript and a low abundance light induced transcript migrating

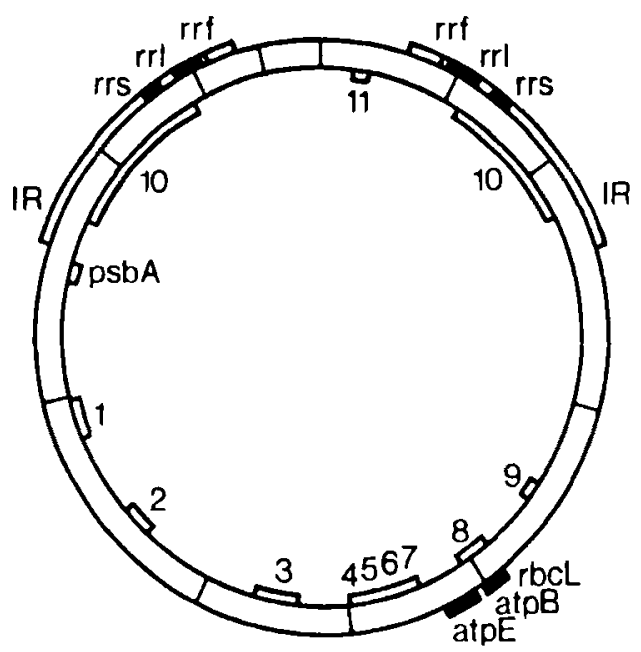

Figure 11. A map of the barley chloroplast genome.

The genome is oriented by the inverted repeats (IR) and the PstI sites. The presumptive positions of the genes rrs, $\mathrm{rrl}$, rrf, atpB, atpE and $\mathrm{rbcL}$ are shown with the black bars on the outside of the circle. The putative position of the photogene 32 (psbA) and the regions coding for light induced transcripts are shown with open bars on the inside. The numbers associated with these regions refer to the transcripts summarized in Table IV. 
slightly slower than the $3.5 \mathrm{~kb}$ transcript. This figure also illustrates the hybridization artefacts frequently observed in the three rRNA bands, which appear light and bordered by unspecific accumulations of hybridizing molecules.

The $\mathbf{h}$ - and $\mathbf{i}$-probes also hybridize with several transcript bands. With the h-probe four major transcripts of $2.8 \mathrm{~kb}, 2.6 \mathrm{~kb}, 1.8 \mathrm{~kb}$ and $0.94 \mathrm{~kb}$ and a minor one of $0.70 \mathrm{~kb}$ are found. In addition three light induced transcripts of 1.0, 0.86 and $0.74 \mathrm{~kb}$ are present. The $\mathrm{i}$-probe hybridizes with transcripts of $2.8 \mathrm{~kb}, 2.6 \mathrm{~kb}, 2.1 \mathrm{~kb}, 1.7 \mathrm{~kb}$ and $0.75 \mathrm{~kb}$. Here, the $2.1 \mathrm{~kb}$ and the $0.75 \mathrm{~kb}$ transcripts appear light induced. As discussed in section 3.5, the i-fragment contaminated the $\mathbf{h}$ fragment. This is reflected by the finding of the 2.8 and $2.6 \mathrm{~kb}$ transcripts with both probes, although the contaminated h-probe hybridizes much less with the two transcripts. On the other hand the light induced transcripts of 0.74-0.75 $\mathrm{kb}$ marked by both probes but weaker with the iprobe cannot be explained by contamination. They are either two different transcripts of similar size, or a single transcript overlapping both fragments. The $1.8 \mathrm{~kb}$ and the $1.7 \mathrm{~kb}$ transcripts are clearly distinguished in terms of mobility as well as hybridization response.

The $\mathrm{i}$-fragment is a $4.9 \mathrm{kbp}$ subfragment of the $6.0 \mathrm{kbp}$ HindIII fragment, which contains sequences homologous to $\mathrm{pZmC} 3711$, the maize cpDNA clone covering the rbcL gene and parts of the atpB/atpE-cistron $(27,32)$. According to the analysis reported in section 3.2 . the barley 1.7 kb rbcL transcript starts a few hundred nucleotides from the PstI end of the i-fragment. Therefore, the most abundant mRNA in the plastids appears only with a moderate hybridization intensity. The transcript extends into the $\mathbf{j}$ fragment. The dicistronic atpB/atpE-transcript found in this region of the maize cpDNA is 2.2 $\mathrm{kb}$. The $\mathrm{i}$-fragment hybridizes with a transcript of $2.1 \mathrm{~kb}$, which is light induced and therefore cannot be the barley atpB/atpE mRNA. Thus remain the $2.6 \mathrm{~kb}$ and $2.8 \mathrm{~kb}$ RNAs as candidates for encoding of the ATP synthetase $\beta$ - and $\varepsilon$ subunits. This situation is reminiscent of that in spinach chloroplasts, where a $1.98 \mathrm{kbp}$ fragment encoding most of the $\beta$ - and $\varepsilon$-subunits, hybridizes to more than one, namely three transcripts of $2.4,2.6$ and $2.8 \mathrm{~kb}$, respectively. In pea (53) and wheat (22), like in maize, only a single dicistronic transcript for the two polypeptides is found. The exact nature of the multiple transcripts in the different species will have to be clarified. Barley is sofar unique by the finding of the $2.1 \mathrm{~kb}$ light induced transcript in this region. This transcript also reaches into the $\mathrm{j}$-fragment. It appears to be transcribed from the same piece of double stranded DNA as the rbcL transcript and to extend into the spacer region between the rbcL and the atpB/atpE genes.

The j-fragment hybridizes to two-three transcripts of about $3.9-4.0 \mathrm{~kb}$, which continue into the $8.3 \mathrm{kbp}$ k-fragment. The k-fragment hybridizes to five other major transcripts and to a few minor ones. A minor band around $0.78 \mathrm{~kb}$ appears light induced. The small $(1.4 \mathrm{kbp}) \mathrm{l}$-fragment, which neighbors the $\mathbf{k}$-fragment on one side and a not yet cloned section of the barley cpDNA on the other, hybridizes strongly with a $2.2 \mathrm{~kb}$ transcript which has to transgress into the un-characterized region.

The $8.4 \mathrm{kbp} \mathrm{m}$-fragment also seems to hybridize to a remarkable large number of transcripts. Some of the weaker ones can be removed by washing at higher temperature. The two major ones are seen here as a $1.6 \mathrm{~kb}$ RNA and a $0.76 \mathrm{~kb}$ RNA.

\subsubsection{The inverted repeat and the small single copy region}

Two thirds of the inverted repeat DNA sequences are covered by two sets of fragments (n,o and $t, u)$. Results of hybridizations with these four probes are shown in the bottom half of Figure 8 and in Figure 9. The $5.8 \mathrm{kbp}$ probes $\mathbf{n}$ or $\mathbf{u}$, which are positioned towards the large single copy region, hybridize to a large number of low abundance transcripts in the high molecular size region. Some of these appear light induced. However, prolonged autoradiography shows that most transcripts are also present among etioplast RNA molecules. A single major transcript of 1.6 $\mathrm{kb}$ is possibly shared with $\mathbf{m}$, the adjacent fragment which contains a portion of the inverted repeat at its end. Fragment $\mathbf{n}$ hybridizes to traces of a very large light induced transcript (not visible in Figure 8) that appears to cover a large section of the inverted repeat. This transcript is clearly seen in the $\mathbf{0}$ - and $\mathbf{t}$-hybridizations, which 
also exhibit the powerful responses of the $16 \mathrm{~S}$ rRNA and the large fragment of the 23S rRNA. In addition to these major transcripts, a set of three transcripts is seen in the 3.1 to $3.5 \mathrm{~kb}$ region. Some weakly responding bands (above 3.9 $\mathrm{kb}$ ) are more pronounced in the light than in the dark and may correspond to transcript bands of the $n$ and $y$ hybridizations.

It thus appears that the population of transcripts originating from the inverted repeat is very complex. The possibility for the involvement of a processing system creating a large number of semi-stable intermediates or precursors from larger primary transcripts cannot be excluded. A closer analysis of the inverted repeat with smaller probes, S1-nuclease protection experiments and in vitro transcription studies, will improve the understanding of these data.

The small single copy region is covered by the four probes $\mathbf{p}, \mathbf{q}, \mathbf{r}$ and $\mathbf{s}$. There is a gap of $2.5 \mathrm{kbp}$ between the o-fragment and the p-fragment, whereas the s-fragment goes into the inverted repeat and adjoins the t-fragment. Hybridization results are shown in Figure 8 , between the two sets of inverted repeat hybridizations. The sprobe hybridizes to inverted repeat transcripts only. These are the three 3.1-3.5 kb transcripts seen with the 0 - and $t$-probes and the small fragment of the $23 \mathrm{~S}$ rRNA. This suggests that the Pstl site separating the $t$ - and the s-fragments is very close to the $23 \mathrm{~S}$ rRNA fragmentation point. Furthermore, since the s-fragment subclone pHvC68 gives a hybridization response quite similar to the s-fragment itself, it is possible that the three 3.1-3.5 kb transcripts are different $23 \mathrm{~S}$ rRNA precursors, which may also include a $4.5 \mathrm{~S}$ rRNA (6).

Hybridization with the p-probe was unfortunate, but it does show a number of weak bands in the 3.0 to $4.0 \mathrm{~kb}$ size class, a minor transcript of $1.3 \mathrm{~kb}$ and a fairly abundant light induced transcript of $0.90 \mathrm{~kb}$, which may reach into the qfragment. The q-probe reveals two transcripts of $3.0 \mathrm{~kb}$ and $4.0 \mathrm{~kb}$ which may also extend back into the p-fragment. Additionally, three transcripts of $0.90 \mathrm{~kb}, 0.75 \mathrm{~kb}$ and $0.68 \mathrm{~kb}$ show up. The latter is quite abundant. There might also be two transcripts in the $2.0-2.4 \mathrm{~kb}$ size class. The background in the 8 hour track of this hybridization as well as in the p-hybridization, suggest the presence of sequences in both fragments which may correspond to an easily degraded or a rapidturnover transcript of high molecular weight. Since it causes background mainly in the 8 hour track, its synthesis could be light induced.

The r-probe hybridizes with three transcripts of $2.5,1.2$ and $0.84 \mathrm{~kb}$. The $1.2 \mathrm{~kb}$ transcript hybridizes quite strongly, suggesting that it is fairly abundant.

\subsubsection{Light regulated RNA synthesis}

Several investigators have reported on the synthesis in chloroplasts of a 32,000 dalton membrane polypeptide during development of plastids $(3,14,37,44,55)$. This yrotein is synthesized as a larger precursor of species dependent size and is processed to its natural size during incorporation into the photosynthetic membranes probably as a component of photosystem II. In vitro translation of $\mathrm{mRNA}$ yields a polypeptide which shares features with a protein component isolated from photosynthetic membranes or photosystem if particles $(3,44)$. it aiso appears to be the same protein which will bind photosystem II uncouplers such as DCMU and triazine herbicides (44). Furthermore it was found that the control for synthesis of the 32,000 dalton protein is on the transcriptional level. G.LinK (29) demonstrated that synthesis of the mRNA is under phytochrome control and that the mRNA is absent in dark grown mustard seedlings.

These studies have also resulted in the localization of the corresponding gene on several genomes. According to the new terminology, this gene is now termed psbA (6). In the maize cpDNA, this gene was previously termed photogene 32 and is associated with a BamHI fragment, Bam8, which is crossing the border between one of the inverted repeat sequences and the large single copy region (3) in the " 9 o'clock" position of the map shown in Figure 1. The presence of an equivalent $5 \mathrm{kbp}$ BamHI fragment in the barley cpDNA (cf. Figure 4), the failure in finding sequences corresponding to this fragment in the barley cpDNA clones investigated and the absence of an abundant light induced transcript of the correct size $(1.2 \mathrm{~kb})$ in the transcript studies reported here, suggest that the location of this gene in the barley genome is equivalent to that in the maize genome. I have been 
Table IV.

The light induced transcripts of the barley chloroplast DNA.

\begin{tabular}{|c|c|c|c|}
\hline Number & Fragment & Size, $k b$ & $\begin{array}{l}\text { Hybridization } \\
\text { Response }\end{array}$ \\
\hline 1 & $\mathbf{a} 1 / \mathbf{a} 2$ & 0.86 & medium to strong \\
\hline 2 & b,c & 2.95 & weak \\
\hline 3 & g & 3.5 & very weak \\
\hline 4 & $\mathbf{h}$ & 1.0 & medium \\
\hline 5 & h & 0.86 & weak \\
\hline 6 & $\mathbf{h}$ & 0.74 & medium \\
\hline 7 & $\mathbf{i}$ & 0.75 & weak \\
\hline 8 & $\mathbf{i}(j ?)$ & 2.1 & medium \\
\hline 9 & $\mathbf{k}$ & 0.78 & very weak \\
\hline 10 & $\mathbf{n}, \mathbf{0}+\mathbf{t}, \mathbf{u}$ & $>6.0$ & strong \\
\hline 11 & $\mathbf{p , q}$ & 0.90 & medium \\
\hline
\end{tabular}

able to identify 11 other photogenes, that is genes only transcribed after illumination. These are located at various positions throughout the barley cpDNA as shown in Figures 10 and 11. The characteristics of these 11 light induced transcripts are listed in Table IV.

It will be interesting to see, if all these photogenes are transcribed under the control of the phytochrome light receptor system. Nucleotide sequence analysis of the regions flanking the genes might reveal common features of promotor and terminator sequences characteristic for light controlled gene expression.

In these experiments no transcripts have been found which are synthesized in the dark, but not in the light. However, it may be noted that these experiments cover only $81 \%$ of the genome and that a single etioplast RNA preparation has been used. Further studies are required to definitively exclude the existence of light induced repression of cpDNA genes.

\section{CONCLUDING REMARKS}

Conservative analysis of Figure 8 yields 70 transcript bands for the $81 \%$ of the barley cpDNA analysed and these have been drawn in Figure 10. Approximately an additional 20 bands have been seen in the hybridizations (36) but need further confirmation. About 25 to 30 of the 70 transcripts are larger than 3,000 nucleotides, the coding capacity for a 100,000 molecular weight protein. In analogy with the di- cistronic mRNA for the $\beta$ and $\varepsilon$ subunits of the ATP synthetase $\mathrm{CF}_{1}$ the large transcripts could represent polycystronic mRNAs, whereas the majority of the transcripts below 3,000 nucleotides most likely encode a single polypeptide.

Overall comparison of the Northern blots make it clear that the different regions of the chloroplast genome are characterized by unique patterns of transcripts. There are some regions giving rise to few transcript bands, but only fragment $\mathbf{d}$ was devoid of significant hybridization responses. There are several (scattered) cpDNA regions hybridizing to a surprisingly large number of transcripts.

The following possibilities are to be considered in the further elucidation of the multitude of transcripts and the large size of some of them: 1) A given region of the genome can be transcribed from several promotors on the same or on opposite strands resulting in overlapping and/ or divergent transcripts. 2) The large transcripts of a given region could be stable precursors or intermediates for the smaller ones.

Several observations in maize, spinach and Euglena gracilis have documented that both possibilities are realized in chloroplast genomes. Divergent transcripts have been identified for the genome region in maize and spinach containing the atpB/atpE and rbcL genes. The transcription initiation points for a tRNA ${ }^{\text {His }}$ and an unknown $1.6 \mathrm{~kb}$ transcript are found within a few basepairs on opposite strands of the DNA resulting in slightly overlapping transcripts (40). As already mentioned one strand of the region encoding the $\beta$ and $\varepsilon$ subunits of $C F_{1}$ in spinach is transcribed into three RNA molecules with sizes of 2.8, 2.6 and $2.4 \mathrm{~kb}$, respectively (53). It is not yet known whether the three transcripts originate from separate initiation points or whether post-transcriptional processing at the termini takes place. It will be of further interest to see if all three transcripts can be translated into the protein products. In contrast the atpB/atpE genes of maize (27) are transcribed into a single $2.2 \mathrm{~kb}$ mRNA molecule originating at an initiation point 300 bp upstream from the ATG methionine triplet and with promotor consensus sequences at -10 and -35 nucleotides upstream from the initiation point.

Precursor RNA molecules and splicing inter- 
mediates are examplified by the maize (45) and Euglena (18) tRNA genes containing introns. The rbcL gene for the large subunit of ribulose bisphosphate carboxylase in Euglena (46) contains introns, while this gene for maize, spinach and tobacco is devoid of intervening sequences. A refined analysis of some of the heavily transcribed regions of barley cpDNA will reveal whether the considered possibilities suffice to explain the large number of transcripts and their size distributions.

Tightly clustered transcription of genomes is characteristic for viruses, e.g., cauliflower mosaic virus (20), for the $2 \mu$ DNA plasmid of yeast (10) and has to be postulated for mammalian mitochondrial genomes (3). Also prokaryotic genomes, with which chloroplast genomes are often compared, encode overlapping and/or divergent transcripts (39). The large number of transcripts of unknown function observed in the mentioned cases as well as in plastids tell that many proteins with as yet undiscovered functions are involved in cellular metabolism. In vitro translation of total plastid RNA from spinach results in a large number of protein products (8) supporting the notion gained in this work that cpDNA encodes a large number of different proteins, possibly in excess of 100 . This is also in agreement with the observations that $\mathrm{E}$. coli RNA polymerase can bind to most restriction endonuclease fragments tested from spinach cpDNA and that most fragments can hybridize with radioactively labelled plastid RNA (52). Nucleotide sequencing of cpDNA regions which by Northern hybridization have given evidence for tightly clustered transcription will provide successively better estimates for the number of proteins encoded by the chloroplast genome.

\section{ACKNOWLEDGEMENTS}

The expertise and help provided by $\mathrm{dr}$. S. Holmberg, dr. A. BRandt from the Carlsberg Laboratory and professor K. MARCKER from the Institute of Molecular Biology, University of Aarhus is gratefully acknowledged. Technical assistance and assistance in the preparation of this manuscript was kindly provided by Ms. INGA Olsen, Ms. G. Bank, Ms. A.-S. Steinholz and Ms. N. Rasmussen. Professor D.von Wettstein is thanked for help in putting this paper together. Financial support for this work has in part been provided by the Commission of the European Communities, contract No. ESD-013-DK of the Solar Energy Programme.

\section{REFERENCES}

1. Alwine, J.C., D.J. Kemp, B.A. PARKer, J. RelSER, J. Renart, G.R. Stark \& G.M. WAHL: Detection of specific RNAs or specific fragments of DNA by fractionation in gels and transfer to diazobenzyloxymethyl paper. In: Methods in Enzymology 68, R. Wu, ed., pp 220-242 (1979) Academic Press New York and London.

2. BEDBROOK, J.R. \& L. BOGORAD: Endonuclease recognition sites mapped on Zea mays chloroplast DNA. Proc. Natl. Acad. Sci. USA 73, 4309-4313 (1976)

3. Bedbrook, J., G. Link, D.M. Coen, L. Bogorad \& A. RICH: Maize plastid gene expressed during photoregulated development. Proc. Natl. Acad. Sci. USA 75, 3060-3064 (1978)

4. Bibb, M.J., R.A. VAN Etten, C.T. Wright, M.A. WALBERG \& D.J. Clayton: Sequence and gene organization of mouse mitochondrial DNA. Cell 26, 167-180 (1982)

5. Birnioim, H.C. \& J. Doly: A rapid alkaline extraction procedure for screening recombinant plasmid DNA. Nucl. Acids Research 7, 1513-1520 (1979)

6. Bohnert, H.J., E.J. Crouse \& J.M. SChMitT: Organization and expression of plastid genomes. In: Encycl. Plant Physiol. vol 14B, pp. 475-530, B. Parthier and D. Boulter eds., (1982) Springer Verlag, Berlin, Heidelberg

7. Bolivar, F.: Construction and characterization of new cloning vehicles.III. Derivatives of plasmid pBR322 carrying unique EcoRI sites for selection of EcoRI generated recombinant DNA molecules. Gene 4, 121-136 (1978)

8. Bottomley, W. \& P.R. Whitfeld: Cell-free transcription and translation of total spinach chloroplast DNA. Eur. J. Biochem. 93, 31-39 (1979)

9. Bowman, C.M., B. Koller, H. Delius \& T.A. DYER: A physical map of wheat chloroplast DNA showing the location of the structural genes for the ribosomal RNAs and the large subunit of ribulose 1,5-bisphosphate carboxylase. Mol. gen. Genet. 183, 93-102 (1981)

10. BROACH, J.R., J.F. AtKins, C. MCGill \& L. CHOw: Identification and mapping of the tran- 
scriptional products of the yeast plasmid, $2 \mu$ circle. Cell 16, 827-839 (1979)

11. Chu, N.M. \& K.K. TewarI: Arrangement of the ribosomal RNA genes in chloroplast DNA of Leguminosae. Mol. gen. Genet. 186, 23-32 (1982)

12. Chu, N.M., K.K. Oishi \& K.K. Tewari: Physical mapping of the pea chloroplast DNA and localization of the ribosomal RNA genes. Plasmid 6, 279-292 (1981)

13. Cohen, S.N., A.C.Y. Chang \& L. Hsu: Nonchromosomal antibiotic resistance in bacteria: Genetic transformation of Escherichia coli by R-factor DNA. Proc. Natl. Acad. Sci. USA 69, 2110-2114 (1972)

14. Driesel, A.J., J. SPEIRS \& H.J. BOHNERT: Spinach chloroplast mRNA for a 32,000 dalton polypeptide. Size and localization on the physical map of the chloroplast DNA. Biochim. Biophys. Acta. 610, 297-310 (1980)

15. Driesel, A.J., E.J. Crouse, K. Gordon, H.J. Bohnert, R.G. Herrmann, A. Steinmetz, M. Mubumbila, M. Keller, G. Burkard \& J.H. WEIL: Fractionation and identification of spinach chloroplast transfer RNAs and mapping of their genes on the restriction map of chloroplast DNA. Gene 6, 285-306 (1979)

16. DenhardT, D.T.: A membrane-filter technique for the detection of complementary DNA. Biochem. Biophys. Res. Commun. 23, 641-646 (1966)

17. Gordon, K.H.J., E.J. Crouse, H.J. Bohnert \& R.G. HERRMANN: Restriction endonuclease cleavage site map of chloroplast DNA from Oenothera parviflora (Euoenothera Plastome IV). Theor. Appl. Genet. 59, 281-296 (1981)

18. Gruissem, W., D.M. Prescott, B.M. GreenBERG \& R.B. HALLICK: Transcription of E. coli and Euglena chloroplast tRNA gene clusters and processing of polycistronic transcripts in a Hela cell-free system. Cell 30, 81-92 (1982)

19. Guidelines for research involving DNA molecules Federal Register U.S. 47 (77) 17180-17198 (1982)

20. Guilley, H., R.K. Dudley, G. Jonard, E. BalAZS \& K.E. RICHARDS: Transcription of cauliflower mosaic virus DNA: Detection of promotor sequences and characterization of transcripts. Cell 30: 763-773 (1982)

21. Howe, C.J., A.D. Auffret, A. Doherty, C.M. Bowman, T.A. Dyer \& J.C. Gray: Location and nucleotide sequence of the gene for proton translocating subunit of wheat chloroplast ATP synthase. Proc. Natl. Acad. Sci. USA 79, 69036908 (1982)
22. Howe, C.J., C.M, Bowman, T.A. DYer \& J.C. GRAY: Localization of wheat chloroplast genes for the beta and epsilon subunits of ATP synthase. Mol. gen. Genet. 186, 525-530 (1982)

23. Kannangara, C.G., S.P. Gough, B. Hansen, J.N. Rasmussen \& D.J. Simpson: A homogenizer with replaceable razor blades for bulk isolation of active barley plastids. Carlsberg Res. Commun. 42, 431-440 (1977)

24. Koller, B., H. Delius \& T.A. Dyer: The organization of the chloroplast DNA in wheat and maize in the region containing the LS gene. Eur. J. Biochem. 122, 17-23 (1982)

25. KolodNER, R. \& K.K. TewarI: The molecular size and conformation of the chloroplast DNA from higher plants. Biochim. Biophys. Acta 402, 372-390 (1975)

26. Kolodner, R. \& K.K. Tewari: Inverted repeats in chloroplast DNA from higher plants. Proc. Natl. Acad. Sci. USA 76, 41-45 (1978)

27. Krebbers, E.T., I.M. LaRrinua, L. McINTOSH \& L.BOGORAD: The maize chloroplast genes for the $\beta$ and $\varepsilon$ subunits of the photosynthetic coupling factor $\mathrm{CF}_{1}$ are fused. Nucl. Acids Res. 10, 4085-5002 (1982)

28. Lehrach, H., D. Diamond, J.M. Wozney \& H. BOEDTKER: RNA molecular weight determinations by gel electrophoresis under denaturing conditions, a critical reexamination. Biochemistry 16, 4743-4752 (1977)

29. LiNK, G.: Phytochrome control of plastid mRNA in mustard (Sinapis alba L.). Planta 154, 81-86 (1982)

30. Malnoe, P., J.-D. Rochaix, N.H. Chua \& P.-F. SPAHR: Characterization of the gene and messenger RNA of the large subunit of ribulose 1,5bisphosphate carboxylase in Chlamydomonas reinhardii. J. Mol. Biol. 133, 417-434 (1979)

31. Maniatis, T., E.F. Fritsch \& J. Sambrook: Electrophoresis of RNA through gels containing formaldehyde. In: Molecular cloning. A laboratory manual. pp 202-203, Cold Spring Harbor Laboratory 1982.

32. McIntosh, L., C. Poulsen \& L. Bogorad: Chloroplast gene sequence for the large subunit of ribulose bisphosphate carboxylase of maize. Nature 288, 556-560 (1980)

33. Oishi, K., T. Sumnicht \& K.K. Tewari: Messenger ribonucleic acid transcript of pea chloroplast deoxyribonucleic acid. Biochemistry 20, 5710-5717 (1981)

34. PALmer, J.D. \& W.F. Thompson: Clone banks of the mung bean, pea and spinach chloroplast genomes. Gene 15, 21-26 (1981)

35. PALMER, J.D. \& W.F. ThOMPSON: Chloroplast 
DNA rearrangements are more frequent when a large inverted repeat sequence is lost. Cell 29 , 537-550 (1982)

36. Poulsen, C.: The in vivo transcriptional activity of the barley chloroplast genome. In: Structure and Function of Plant Genomes. O. Ciferri and L. Dure III, eds., Plenum Press, New York (1982), in press

37. Reisfeld, A., A.K. Mattoo \& M. Edelman: Processing of a chloroplast-translated membrane protein in vivo. Analysis of the rapidly synthesized 32000-dalton shield protein and its precursor in Spirodela oligorrhiza. Eur. J. Biochem. 124, 125-129 (1982)

38. Rigby, P.W.J., M. Dieckmann, C. Rhodes \& P. BERG: Labeling deoxyribonucleic acid to high specific activity in vitro by nick translation with DNA polymerase I. J. Mol. Biol. 133, 237 251 (1977)

39. Schwarz, E., G. Scherer, G. Hobom \& H. Kossel: Nucleotide sequence of cro, $\mathrm{CII}$ and part of the Ogene in phage $\lambda$ DNA. Nature 272 , 410-414 (1978)

40. Schwarz, Z., S.O. Jolly, A. Steinmetz \& L.BOGORAD: Overlapping divergent genes in the maize chloroplast chromosome and in vitro transcription of the gene for $\mathrm{tRNA}^{\text {His. }}$. Proc. Natl. Acad. Sci. USA 78, 3423-3427 (1981)

41. Shinozaki, K. \& M. Sugiura: Sequence of the intercistronic region between the ribulose-1,5bisphosphate carboxylase/oxygenase large subunit and the coupling factor $\beta$ subunit gene. Nucl. Acids Res. 10, 4923-4934 (1982)

42. Shinozaki, K. \& M. Sugrura: The nucleotide sequence of the tobacco chloroplast gene for the large subunit of ribulose bisphosphate carboxylase-oxygenase. Gene 20, 91-102 (1982)

43. Southern, E.M.: Detection of specific sequences among DNA fragments separated by gel electrophoresis. J. Mol. Biol. 98, 503-517 (1975)

44. Steinback, K.E., L. McIntosh, L. Bogorad \& C. ARNTZEN: Identification of the triazine receptor protein as a chloroplast gene product. Proc. Natl. Acad. Sci. USA 78, 7463-7467 (1981)

45. Steinmetz, A., EJ. Gubbins \& L. Bogorad: The anticodon of the maize chloroplast gene for tRNA ${ }^{\text {Leu }}$ is split by a large intron. Nucl. Acids Res. 10, 3027-3037 (1982)
46. Stiegler, G.L., H.M. Matthews, S.E. BingHAM \& R.B. HaLlick: The gene for the large subunit of ribulose-1,5-bisphosphate carboxylase in Euglena gracilis chloroplast DNA: location, cloning and evidence for an intervening sequence. Nucl. Acids Res. 10, 3427-3444 (1982)

47. Takaiwa, F. \& M. Sugiura: Nucleotide sequence of the $16 \mathrm{~S}-23 \mathrm{~S}$ spacer region in an rRNA gene cluster from tobacco chloroplast DNA. Nucl. Acids Res. 10, 2665-2676 (1982)

48. Takaiwa, F. \& M. Suglura: The complete nucleotide sequence of a 23-S rRNA gene from tobacco chloroplasts. Eur. J. Biochem. 124, 1319 (1982)

49. Wahl, G.M., M. Stern \& G.R. Stark: Efficient transfer of large DNA fragments to diazobenzyloxymethyl-paper and rapid hybridization by using dextran sulfate. Proc. Natl. Acad. Sci. USA 76, 3683-3687 (1979)

50. Westhoff, P, N. Nelson, H. Bunemann \& R.G. HerrmanN: Localization of genes for coupling factor subunits on the spinach plastid chromosome. Current Genetics 4, 109-120 (1981)

51. Wienand, U., Z. Schwarz \& G. Feix: Electrophoretic elution of nucleic acids from gels adapted for subsequent biological tests. FEBS Letters 98, 319-323 (1979)

52. ZECH, M., M.R. HARTLEY \& H.J. BOHNERT: Binding sites of E. coli DNA-dependent RNA polymerase on spinach chloroplast DNA. Current Genetics 4, 37-46 (1981)

53. Zurawski, G., W. Bottomley \& P.R. WhitFELD: Structures of the genes for the $\beta$ and $\varepsilon$ subunits of spinach chloroplast ATPase indicate a dicistronic mRNA and an overlapping translation stop/start signal. Proc. Natl. Acad. Sci. USA 79, 6260-6264 (1982)

54. Zurawski, G., B. Perrot, W. Bottomley \& P.R. Whitfeld: The structure of the gene for the large subunit of ribulose 1,5-bisphosphate carboxylase from spinach chloroplast DNA. Nucl. Acids Res. 9, 3251-3270 (1981)

55. ZURAWSKI, G., H.J. BOHNERT, P.R. WhitFELD \& W. BotTomLeY: Nucleotide sequence of the gene for the $32,000-M_{R}$ thylakoid membrane protein from Spinacia oleracea and Nicotiana debneyi predicts a totally conserved primary translation product of $M_{R} 38,800$. Proc. Natl. Acad. Sci. USA 79, 7699-7703 (1982) 

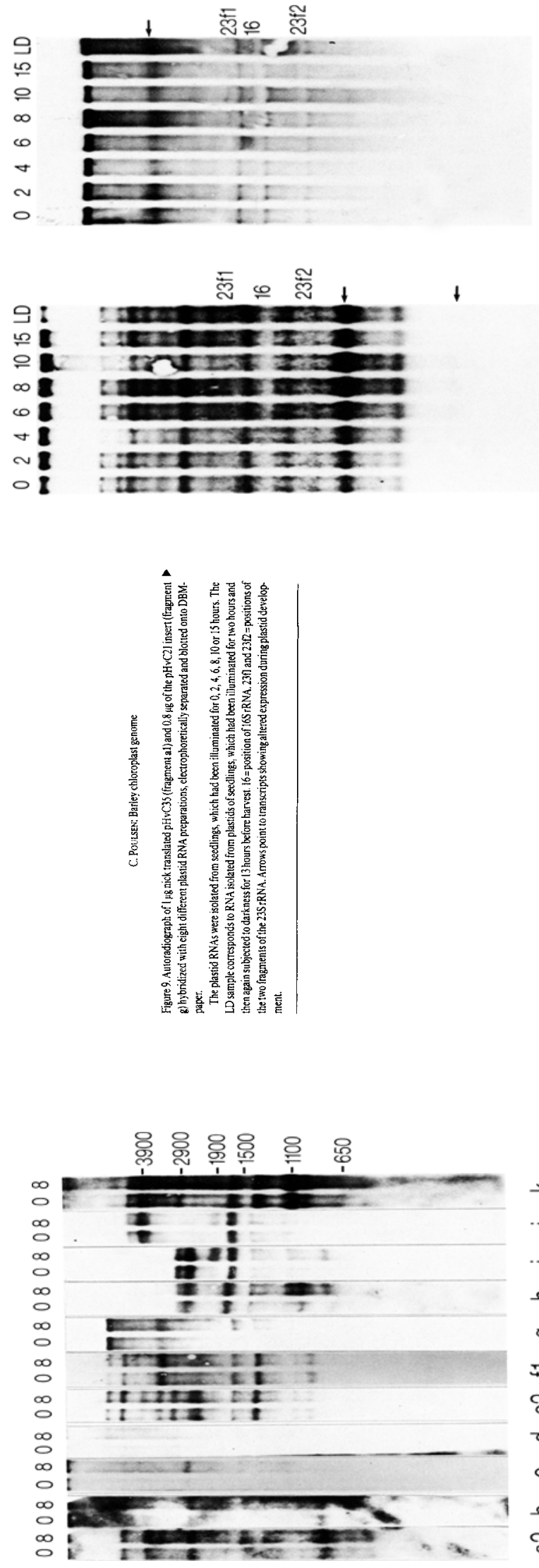
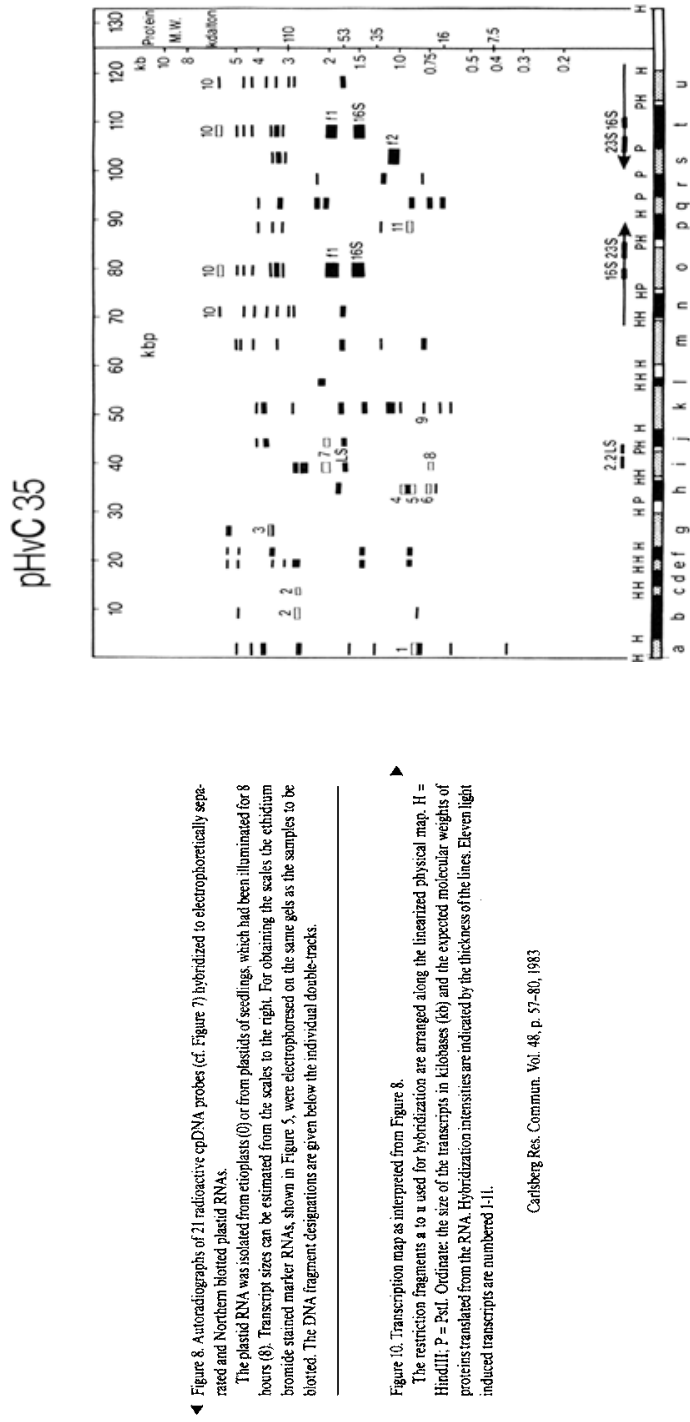

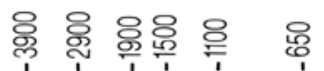

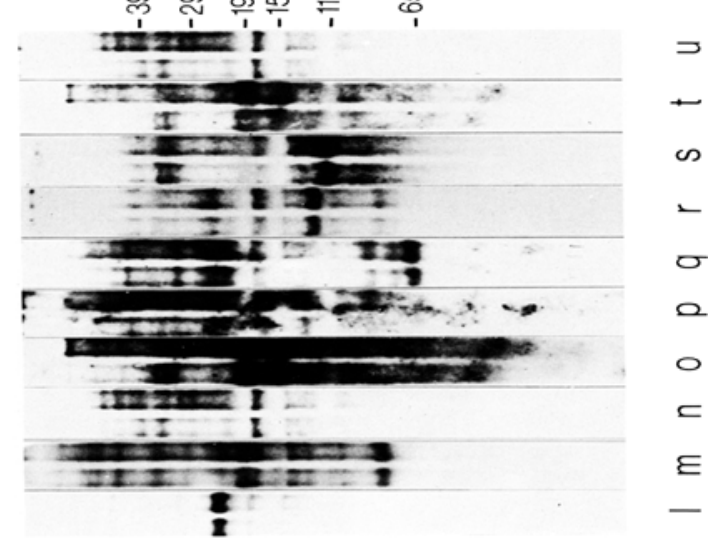

